\title{
Jatropha Curcas Biodiesel: A Lucrative Recipe for Pakistan's Energy Sector
}

\author{
Haseeb Yaqoob ${ }^{1,2}\left(\mathbb{D}\right.$, Yew Heng Teoh ${ }^{1, *(1)}$, Farooq Sher ${ }^{3, *}$, , Muhammad Umair Ashraf ${ }^{4}$, Sana Amjad ${ }^{5}$, \\ Muhammad Ahmad Jamil ${ }^{6}\left(\mathbb{B}\right.$, Muhammad Musaddiq Jamil ${ }^{2}$ and M. A. Mujtaba ${ }^{7}(\mathbb{C})$
}

1 School of Mechanical Engineering, Engineering Campus, University Sains Malaysia, Nibong Tebal, Penang 14300, Malaysia; haseeb.yaqoob@student.usm.my

2 Department of Mechanical Engineering, Khwaja Fareed University of Engineering and Information Technology, Rahim Yar Khan 64200, Pakistan; musaddiq33433@gmail.com

3 Department of Engineering, School of Science and Technology, Nottingham Trent University, Nottingham NG11 8NS, UK

4 Institute of Business, Management and Administrative Sciences, The Islamia University of Bahawalpur, Bahawalpur 63100, Pakistan; muhammad.umair@iub.edu.pk

5 Department of Management Sciences, Khwaja Fareed University of Engineering and Information Technology, Rahim Yar Khan 64200, Pakistan; sana.amjad@kfueit.edu.pk

6 Department of Mechanical and Construction Engineering, Northumbria University, Newcastle Upon Tyne NE1 8ST, UK; muhammad2.ahmad@northumbria.ac.uk

7 Department of Mechanical Engineering, New Campus Lahore, University of Engineering and Technology, Lahore 39161, Pakistan; m.mujtaba@uet.edu.pk

* Correspondence: yewhengteoh@usm.my (Y.H.T.); Farooq.Sher@ntu.ac.uk or Farooq.Sher@gmail.com (F.S.)

Citation: Yaqoob, H.; Teoh, Y.H.; Sher, F.; Ashraf, M.U.; Amjad, S.; Jamil, M.A.; Jamil, M.M.; Mujtaba, M.A. Jatropha Curcas Biodiesel: A Lucrative Recipe for Pakistan's Energy Sector. Processes 2021, 9, 1129. https://doi.org/10.3390/pr9071129

Academic Editor: Davide Papurello

Received: 7 May 2021

Accepted: 23 June 2021

Published: 29 June 2021

Publisher's Note: MDPI stays neutral with regard to jurisdictional claims in published maps and institutional affiliations.

Copyright: (C) 2021 by the authors. Licensee MDPI, Basel, Switzerland. This article is an open access article distributed under the terms and conditions of the Creative Commons Attribution (CC BY) license (https:// creativecommons.org/licenses/by/ $4.0 /)$.
Abstract: One of the greatest challenges of the 21st century is to fulfill the growing energy needs sustainably and cost-effectively. Among the different sources of energy, biodiesel is one of the alternative energy sources that has tremendous potential to become a major mainstream renewable energy mix. Jatropha is an important raw input for biodiesel that provides an ecological and sustainable solution for emerging greenhouse gas emissions over the other biomass feedstock. This paper critically evaluates different factors and presents a SWOT analysis (strengths, weaknesses, opportunities, and threats) and barriers to the adoption of Jatropha biodiesel. In Pakistan, the estimated production of Jatropha biodiesel is expected to be 2.93 million tons, that are calculated from available barren land and possible shortlisted suitable areas for Jatropha plantation. It is $\sim 25 \%$ of the total import (11.84 million tons) of petroleum products, which can save $\sim \$ 2$ billion USD reserves of Pakistan. The cultivation of Jatropha on barren land is an environmentally and economically lucrative approach for Pakistan. This study has real implications for developing a policy framework related to the environment and socio-economic feasibility of Jatropha biodiesel production in Pakistan.

Keywords: renewable energy; alternative fuel; biodiesel; Jatropha Curcas; biomass; emissions and carbon footprints

\section{Introduction}

Energy is paramount to the survival and growth of any economy. Advanced economics does not rely on a single source of energy but rather explores other important feedstock from efficient energy production. The leading demand of the 21st century is to compete with the increasing requirements of energy [1]. Pakistan is the 5th most populous country globally, and its energy requirements and population are increasing day by day [2]. The population of Pakistan in 2010 was 179,424,641, which increased to 220,892,340 in 2020 and is estimated to hit 242.2 million in 2025, as shown in Figure 1 [3]. Pakistan is a developing nation, it requires continuous inclusion of energy in the mainstream channel to meet the demand of the ever-increasing population, and a lack of system up-gradation results in a shortage of energy in the country [4]. Currently, conventional fuels, i.e., oil, natural gas, 
and coal, make up $63 \%$ of the total source of energy in Pakistan, followed by hydroelectric $(26 \%)$, nuclear $(3 \%)$, and renewable energy $(8 \%)$, which is shown in Figure 2.

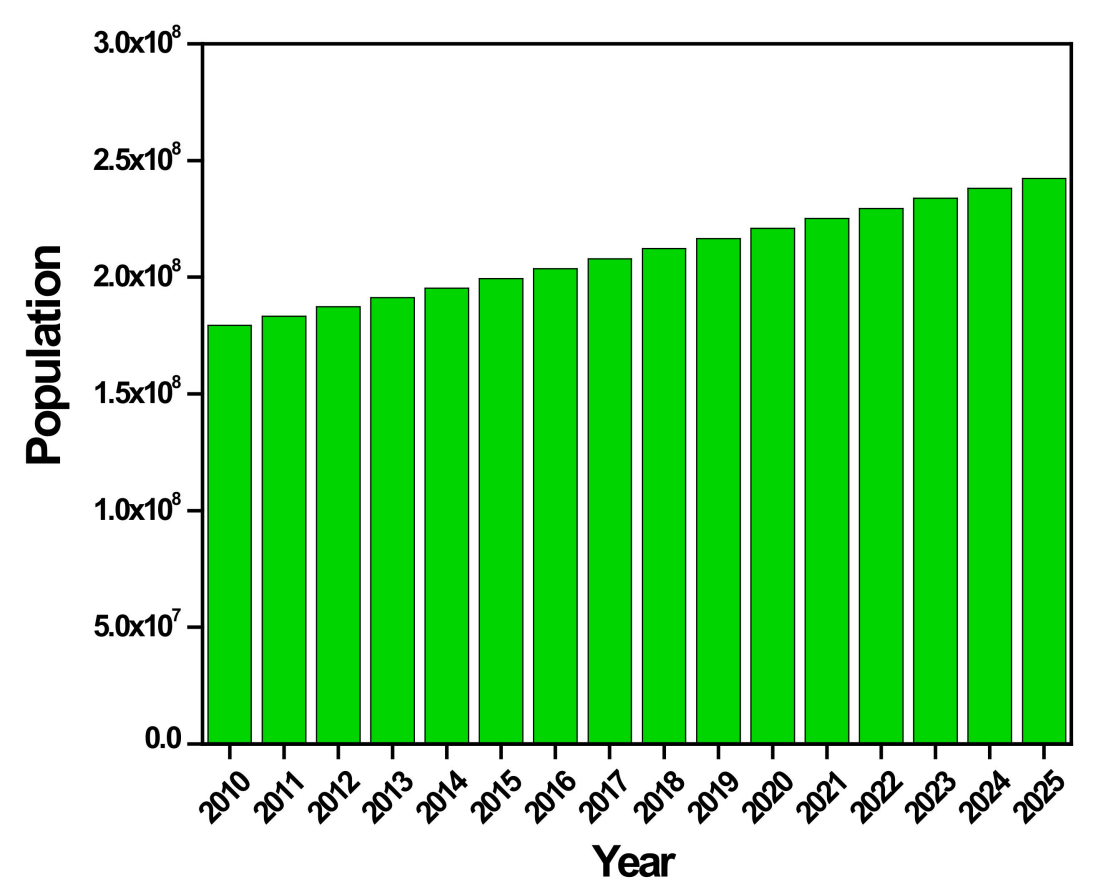

Figure 1. Pakistan's population from 2010 to 2020, along with predictions until 2025 [3].

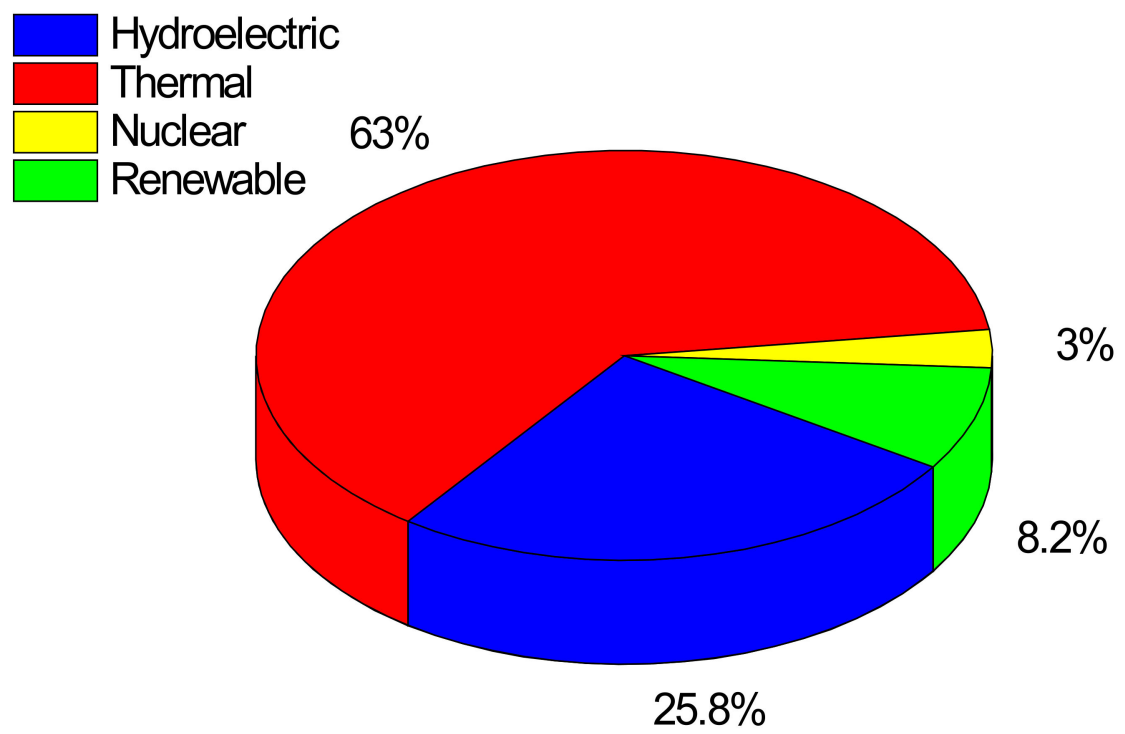

Figure 2. Energy production by different sources in Pakistan in 2018-2019 [2].

The largest consumer of oil/petroleum products is the transport sector, that reached up to $76 \%$ in 2018-2019 (see Figure 3) [2]. The total oil/petroleum consumption was $18,886,507$ tons in 2010-2011, which increased to $24,677,964$ tons in 2017-2018, the total gas consumption was $1,240,671 \mathrm{~mm}$ cft in 2010-2011, which increased to 1,454,697 mm cft in 2017-2018, and the total coal consumption was 7,717,100 metric tons in 2010-2011, which increased to 17,981,100 metric tons in 2017-2018, as shown in Figures 4-6, respectively. Similarly, the oil/petroleum consumption for transport was 8,892,268 tons in 2010-2011, which increased to 16,047,392 tons in 2017-2018, which is shown in Figure 7, but the gas (CNG) consumption for transport was 113,055 mm cft in 2010-2011, which decreased to 70,455 mm cft in 2017-2018, as shown in Figure 8 [5]. 


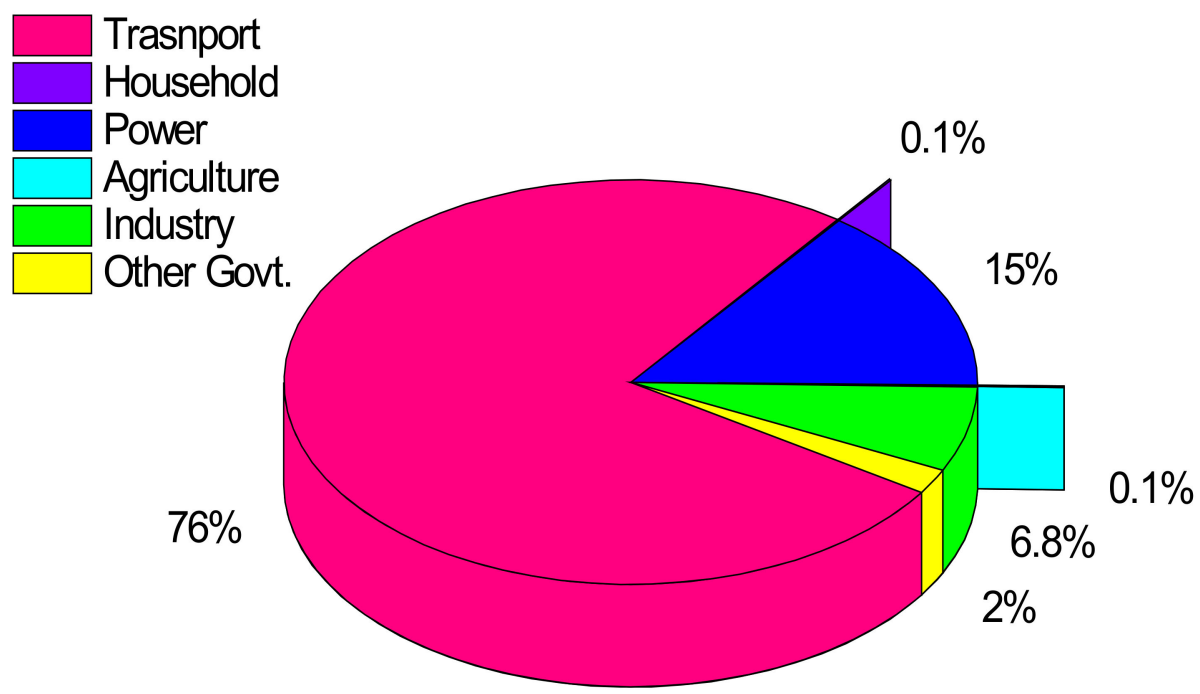

Figure 3. Oil/petroleum products consumption in different sectors of Pakistan in 2018-2019 [2].

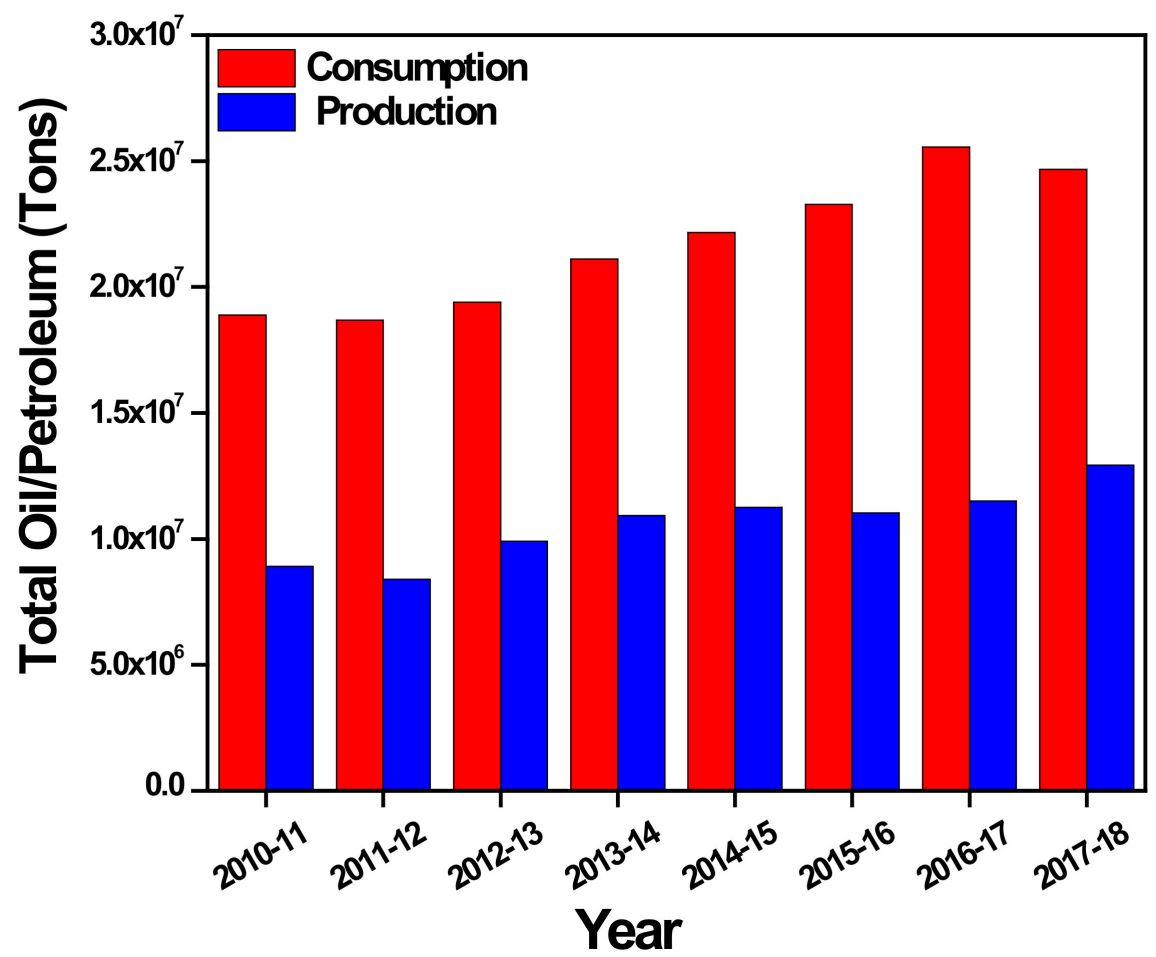

Figure 4. Total production and consumption of oil/petroleum in Pakistan [5]. 


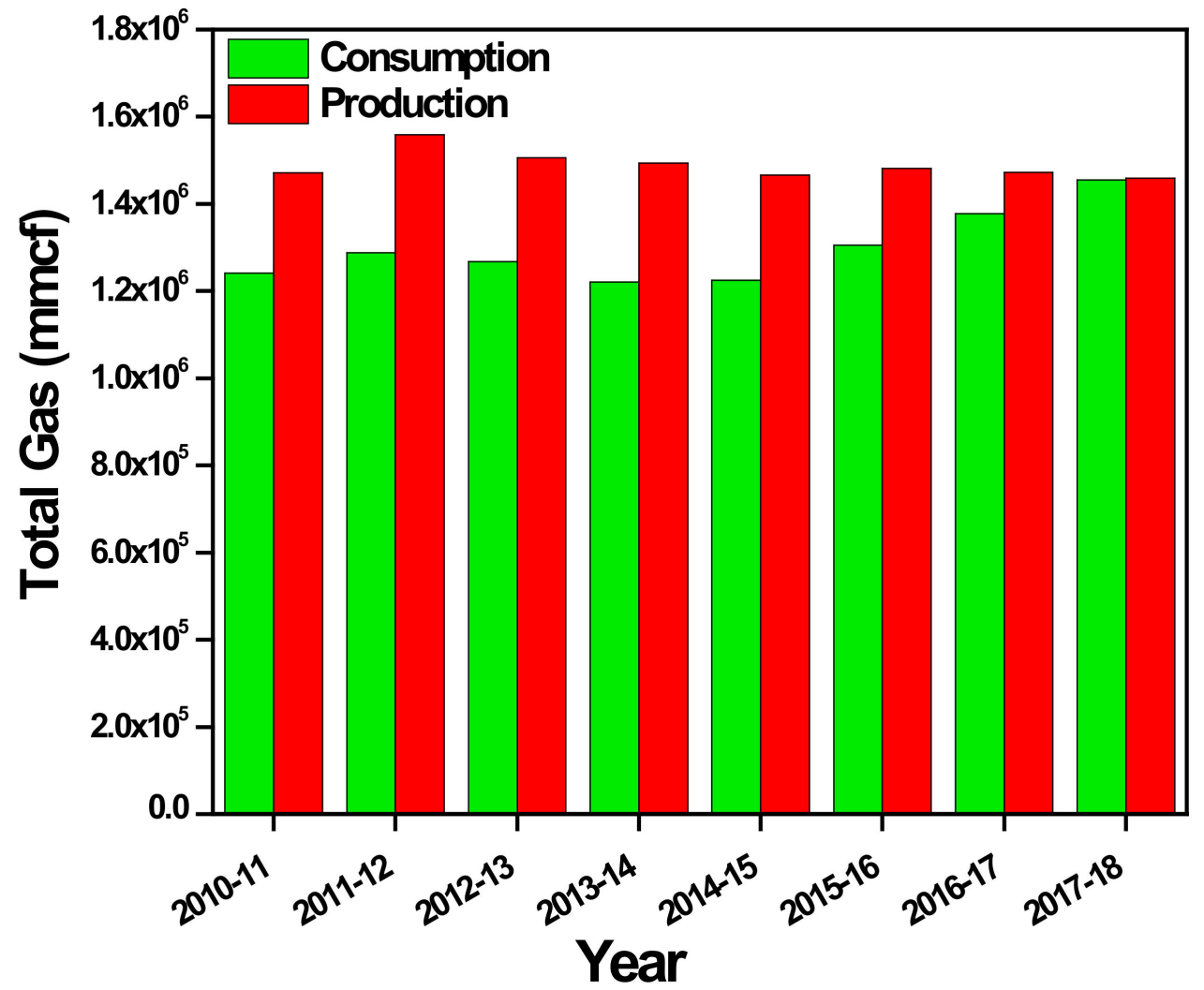

Figure 5. Total production and consumption of gas in Pakistan [5].

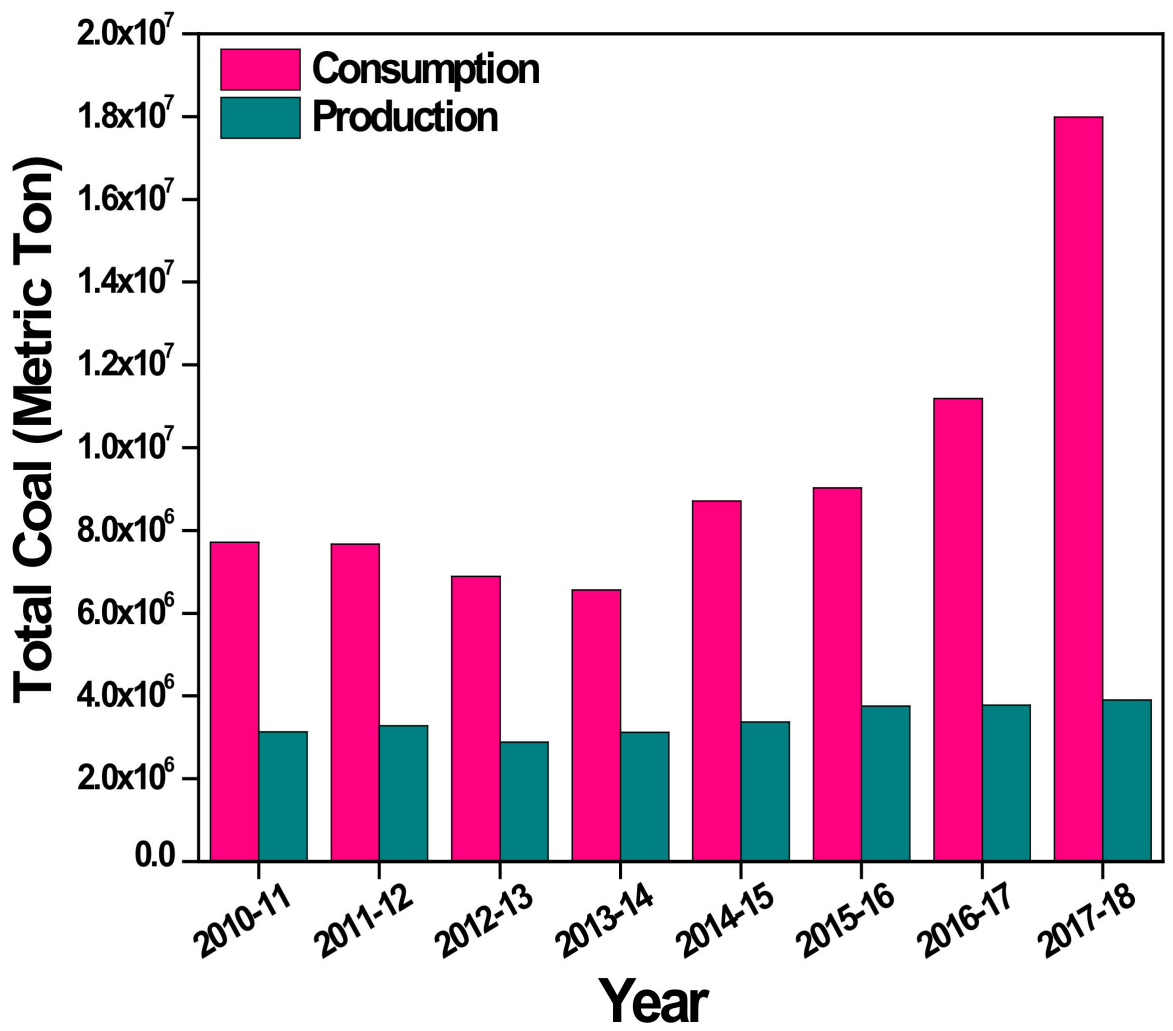

Figure 6. Total production and consumption of coal in Pakistan [5]. 


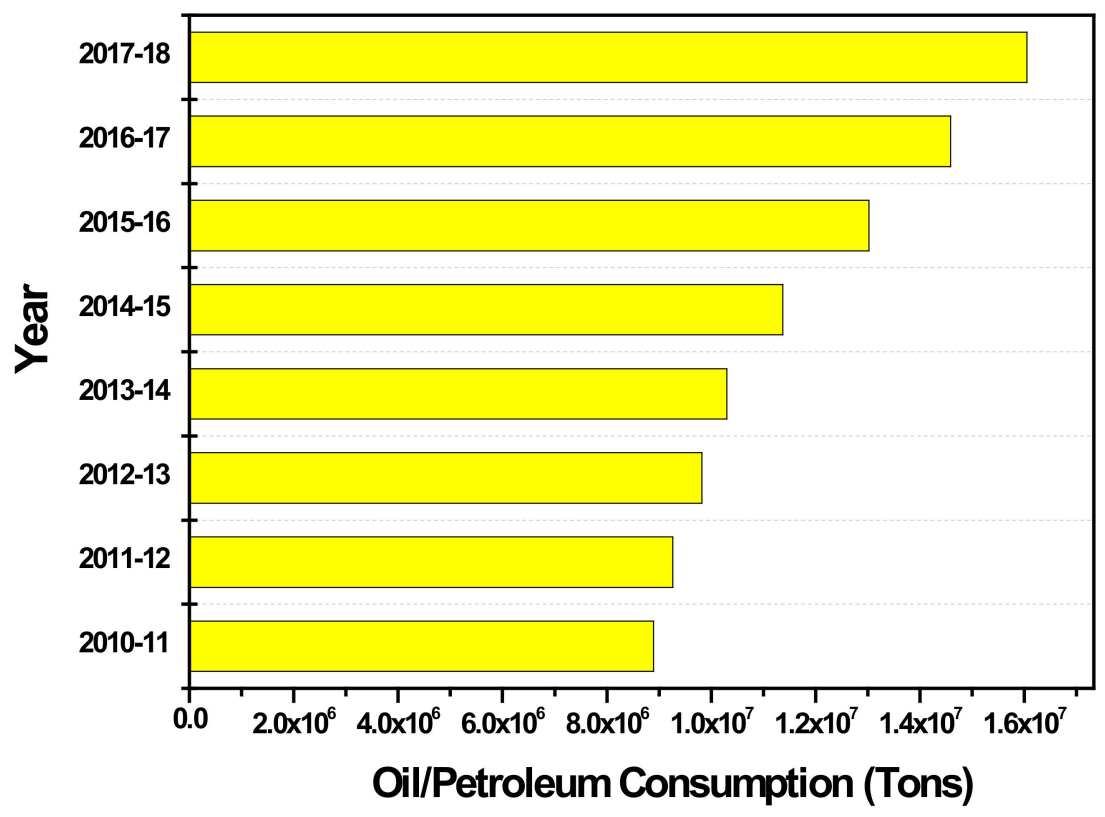

Figure 7. Consumption of oil/petroleum by transport in Pakistan [5].

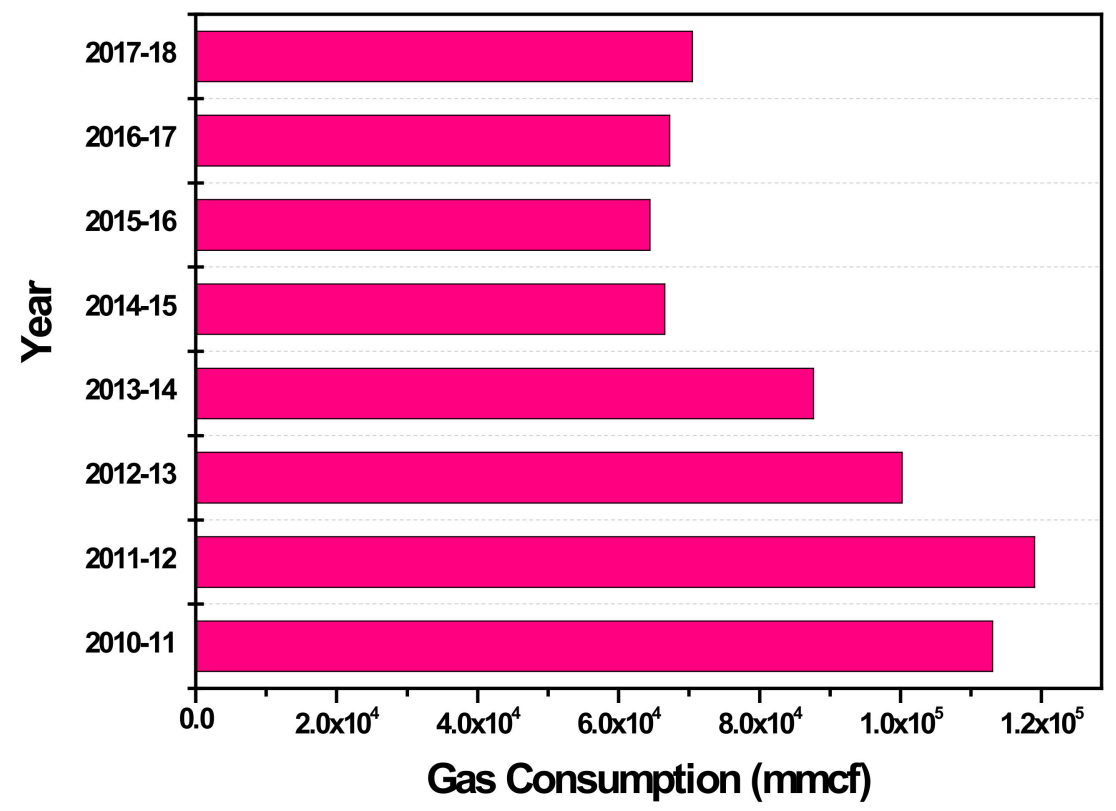

Figure 8. Consumption of gas (CNG) by the transport sector in Pakistan [5].

Energy crises do not just affect the lives of individuals, but also cripple the industry and hence the economic growth [6]. The recent contribution of renewable energy is inadequate in the overall contribution of the country's energy [7]. Through the use of fossil fuels, Pakistan is achieving the requirements of energy [8]. Due to the massive reliance on fossil fuels, there is a load of pressure on the country's economy, and this trend has led to various environmental effects $[9,10]$. Furthermore, as the population of the world increases, due to which the number of vehicles increases, this trend increases the emissions of $\mathrm{CO}_{2}$, and the same trend is happening in Pakistan [11]. Now, Pakistan has enormous energy crises that have forced several industries to close. Therefore, the amounts of emissions of $\mathrm{CO}_{2}$ from the industry have reduced, but there is an increasing trend in the amount of $\mathrm{CO}_{2}$ emissions due to the increasing trend of vehicles [12].

In Pakistan, the $\mathrm{CO}_{2}$ emissions were 154.14 million tons in 2010, which increased to 248.84 million tons in 2019, as shown in Figure 9 [13]. To overcome these problems, 
it is necessary to use renewable [14], reliable, and pollution-free energy sources that can combine social and economic progress along with pollution control $[15,16]$. Such renewable energy sources are primarily biofuels [17-19], waste fuels [20,21], wind [22,23], solar [24], and hydro. Biofuels from these resources are biodegradable, easy to use, and they are aromatic- and sulfur-free [25]. In biofuels, biodiesel is becoming more competitive as a substitute fuel in different energy fields, particularly in transportation [26,27]. Its annual production in 2000 was 15,000 barrels per day, which increased to 289,000 barrels per day in 2008 [28]. In Pakistan, biodiesel is also trending as one of the rapidly growing substitute fuels in the world [29]. Global warming problems resulting from fossil fuel burning force the world to generate sustainable energy from renewable and eco-friendly sources [30]. Biofuel is seen as a viable solution to transport-related energy and environmental issues [31]. Arshad et al. conducted a study on ethanol production from molasses in Pakistan and concluded that the distillery now meets domestic demands of $5 \%$ mixing. Thus, $5 \%$ ethanol, which does not require changes to engines in a vehicle, may be mixed short-term with gasoline fuel [32].

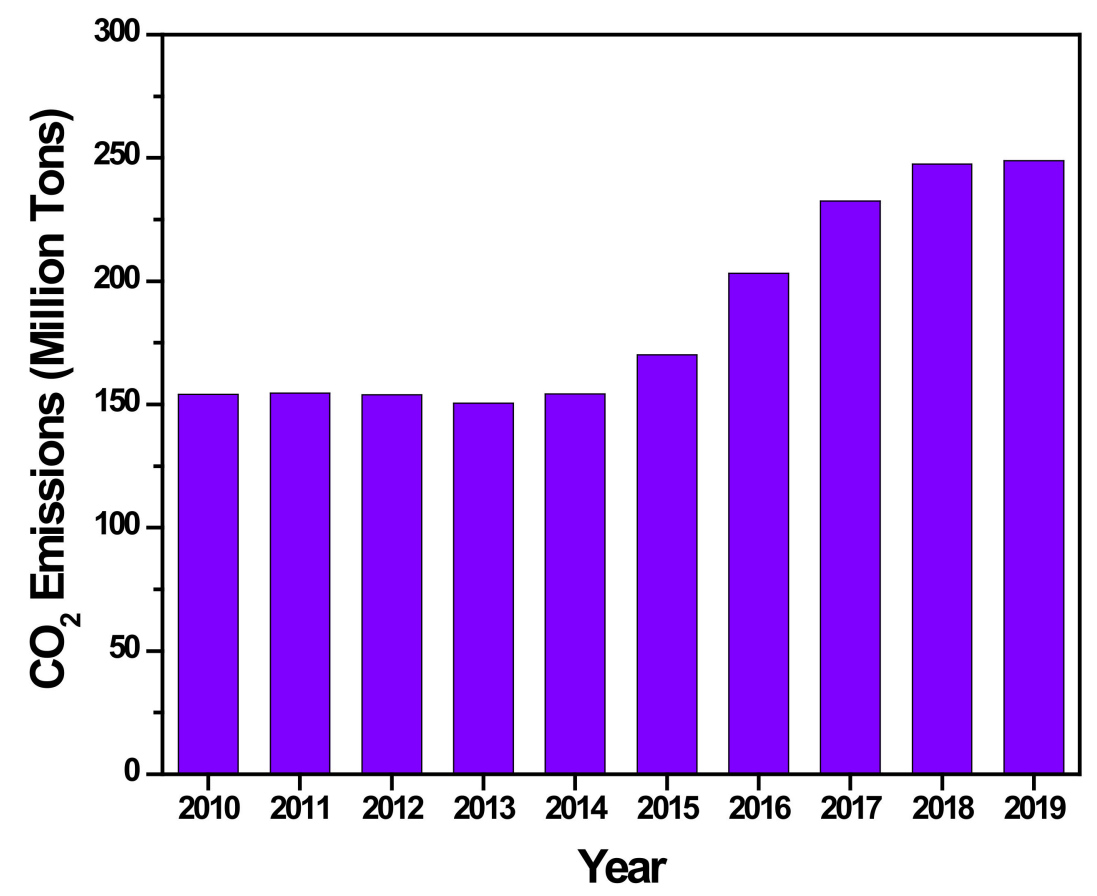

Figure 9. The $\mathrm{CO}_{2}$ emissions in Pakistan from 2010 to 2019 [13].

This study provides a review of the current status and potential of Jatropha Curcas biodiesel in Pakistan. The study begins with the introduction chapter that includes the descriptive presentation of population characteristics, alternative energy sources, and their due consumption proportions, and the periodic data of $\mathrm{CO}_{2}$ emissions is specified. This is followed by the comprehensive overview of biodiesel as renewable energy, which is further divided into some subheadings in which feedstocks, standards, policies, some policy recommendations, benefits and drawbacks, sustainability, and perspectives in Pakistan of biodiesel are summarized. The horticultural detail, growth, applications, properties, and efficiency of the diesel engine of Jatropha Curcas are summarized. Jatropha's influence on Pakistan's biofuel strategies and the current production of Jatropha biodiesel in Pakistan are discussed. Moreover, the potential of Jatropha biodiesel in Pakistan is calculated. The emission, environmental, and socio-economic impacts of the Jatropha Curcas oil as biodiesel are covered. Then, the SWOT analysis and the barriers to biodiesel production from Jatropha are stated. The projected actions are summarized. Finally, the policy suggestions and future routes for the production of biodiesel are covered. This paper indicated that biodiesel output from Jatropha Curcas provides the country with several environmental, 
economic, and social advantages, and can play a major role in addressing Pakistan's energy shortage issue.

\section{Renewable Energy: Biodiesel}

Liquid biofuels are being supported by environmental and economic factors in the global energy matrix [33]. The European Union (EU) set the scientific arrangements and technical requirements for biodiesel as EN 14214, and by the United States of America as ASTM 6751-02. Biodiesel consists of fatty acids and long-chain monoalkyl esters extracted through livestock fats or plant oils (maybe non-edible or edible) [34,35]. Particularly, in comparison with fossil fuel, it is non-toxic, ecofriendly, and biodegradable. The various processing techniques of biodiesel are emulsification, cracking, transesterification, and dilution of the mixing of hydrocarbons [16,36-39]. Transesterification among the above techniques is the best technique. This method allows the oil to convert into esters, and in this method, glycerin is separated out. The biodiesel rests on the surface, from where it can be taken out, and the glycerin settles down on the floor. Ten pounds of alcohol interact in one hundred pounds of oil or fat along with a catalyst to create ten pounds of glycerin and one hundred pounds of biodiesels.

This process requires oil to react with three mol of methanol. Catalytic transesterification is the most widely used process. Three methods can be used for catalytic transesterification: catalysts of alkaline such as $\mathrm{KOH}$ or $\mathrm{NaOH}$, enzymes such as $\mathrm{CH}_{2} \mathrm{~N}_{2}$, and catalysts of acid such as sulfonic, sulfuric, and hydrochloric acids. Several studies found that catalytic alkali methods are more prudent and rapid from all the reactions of catalytic alkali methods [36,40-42], although the method catalyzed by acids provides quite high esters production. Glycerol is a critical by-product of this process used for fuel or used in the superficial industry as just a raw material [43]. Biodiesel is now widely used in the European countries and the United States to reduce environmental contaminants and eliminate reliance on the production of fossil fuels found across various areas in the globe and rising crude petroleum prices [44]. Biodiesel does not include petroleum additives, so it is consistent with traditional fuel and is mixed in any fossil-based gas ratio and from a natural bio-diesel combination. Therefore, biodiesel is now one of the world's most famous forms of biofuels [45].

\subsection{Feedstocks for Biodiesel}

One of the most significant benefits of developing biodiesel as a sustainable power option is the wide variety of feedstocks available for biodiesel processing [46]. More than 350 oil-bearing plants are classified as a possible source for renewable oils, such as soybean, sunflower, palm, cottonseed, safflower oil, peanut oil, and oilseed rape [44,47]. Many other un-edible oils such as neem, Karanja, and Jatropha are also gaining interest [48]. The abundance of fuel sources for producing biodiesel depends on both the country's geographical position and farming activities. The usage of the right raw material is thus critical in maintaining nominal manufacturing costs for biodiesel. Studies have shown that only raw material accounts for more than $75 \%$ of the total cost of manufacturing biodiesel. The feedstock for biodiesel can usually be classified into four major groups [49]:

- Fats of animals: black butter, seaweed, and animal fat.

- Recycled or surplus crude.

- $\quad$ Non-edible vegetable oil: halophytes, Karanja, coral, Jatropha, and ocean plum.

- Edible vegetable oil: rape, sunflower, soybean, coconut oil, and hemp oil.

\subsection{Standards and Policies of Biodiesel}

Worldwide, there are several policies for biodiesel, which have been set out by several countries. These policies have been encouraging biodiesel within the energy mix and raised the goal for the planned utilization of biodiesel. A list of certain biodiesel goals in chosen countries across the world is displayed in Table 1. 
Table 1. Some countries' policies about biofuel.

\begin{tabular}{|c|c|c|}
\hline Country & Biodiesel Policy & Reference \\
\hline USA & $\begin{array}{c}\text { By 2006, the Energy Policy Act } 2005 \text { imposed a commitment of } 400 \text { million gallons of } \\
\text { biofuels in the transport industry. The Energy Independence and Security Act } 2007 \text { set } \\
\text { a goal of } 18 \% \text { renewable energy use in transport fuel by 2022. Oregon also has an } \\
\text { established fuel regulation, whereby } 5 \% \text { biodiesel is required to be blended into } \\
\text { diesel transport. }\end{array}$ & [50-52] \\
\hline EU & $\begin{array}{l}\text { The EU has approved a } 20 \% \text { and } 10 \% \text { renewable fuel standard as the domestic product } \\
\text { consumption in the transport sector by } 2020 \text {. The EU also set out a Sustainable } \\
\text { Low-Carbon Economic roadmap for } 2011 \text {, in which greenhouse gas emissions would } \\
\text { be reduced to } 40 \%, 60 \% \text {, and } 80 \% \text { by } 2030,2040 \text {, and } 2050 \text {, respectively. }\end{array}$ & [53-56] \\
\hline Canada & $\begin{array}{l}\text { Under the Environmental Protection Act } 1999 \text { (BillC-33), 2\% and 5\% of biodiesel } \\
\text { blends in traditional diesel were set as targets. }\end{array}$ & {$[50]$} \\
\hline Thailand & $\begin{array}{c}\text { Thailand also planned to achieve } 5 \% \text { diesel blending with palm oil and } 10 \% \text { ethanol } \\
\text { blending with cassava. }\end{array}$ & [57] \\
\hline Malaysia & $\begin{array}{l}\text { The policy anticipated that diesel of the whole country blended with } 5 \% \text { of palm oil } \\
\text { would generate a demand of } 500,000 \text { tons for palm oil, which is similar to replacing } \\
40-50 \% \text { of the country's supply of palm oil. The increase in the mixing rate occurred } \\
\text { from } 1.3 \% \text { in } 2011 \text { to } 7 \% \text { in } 2015 \text {. The B15 mixing rate will be discussed by } 2020 \text {. }\end{array}$ & {$[52,58]$} \\
\hline Indonesia & $\begin{array}{l}\text { In } 2006 \text {, the Indonesian government developed the first policy of biofuel for the } \\
\text { country, in which they set a plan of covering } 10 \% \text { of transportation fuel with biofuel } \\
\text { by } 2010 \text {. By } 2025 \text {, the contribution of biodiesel in the transport sector will be } 20 \% \text {. }\end{array}$ & [45] \\
\hline Philippines & $\begin{array}{c}\text { The Biofuels Act } 2006 \text { (RA 9367) states that under three months of the act, effectivity at } \\
\text { least } 1 \% \text { of biodiesel will be blended by quantity across all diesel engines offered for } \\
\text { sale in that region, which rises to } 2 \% \text { after two years. This act set out the biofuel policy } \\
\text { to accomplish energy independence by decreasing imported oil, fulfilling } \\
\text { environmental problems, and growing rural jobs and wages. }\end{array}$ & {$[59,60]$} \\
\hline China & $\begin{array}{l}\text { The focus of China's policy is the farming of energy plants and the advancement of } \\
\text { matured technology to produce biofuel. The target of the production of biodiesel by } \\
2020 \text { is } 2 \text { million tons. }\end{array}$ & [55] \\
\hline India & The suggested goal is to blend 20\% ethanol and 5\% biodiesel by 2030 . & [61] \\
\hline
\end{tabular}

The Mid-Term Policy (MTP) was subordinated to upgrades in 2006. Thus, the MTP would excel in this year's latest short-term Renewable Energy (REP) strategy. Given that such a program's instruments would continue to boost the growth of the sustainable energy market in the household by 2014 and beyond, the approach path is then decided. The MTP seems to be the culmination of several years of change, involving experts, advisors, and members from across Pakistan and other nations in exchanging protocols and lessons learned [62,63]. In early 2006, this approach was a successful one [64,65]. In increasing the MTP, renewable energy facilities were aimed at assisting the work of various departments of government. Due to this, the power shortage has increased Pakistan's usage of sustainable technology. The key aims were to promote trade and encourage investment from the private sector by offering opportunities and expenditure and supporting the efficient usage of energy capital and revenue-generating behavior. It aimed to aid in developing specific scientific, organizational, and prepared competencies $[62,66]$.

The Mid-Term Policy was developed in the short term, utilizing an extended summary of alternative options and renewables, to contend with participant interests, decide on policy disagreements, including the knowledge gained, and to establish that sustainable and renewable technologies are being supported. It also proposes a biodiesel strategy that extended opportunities through innovative funding, i.e., alternate energy production funds $[67,68]$. Intending to develop and use biofuel as an alternative fuel in Pakistan, the AEDB (Alternate Energy Production Board) has provided strategic guidelines for reducing import fuel bills, meeting the need for biofuel raw materials, and promoting a pollution-free environment. Additionally, as of 14 February 2008, the National Cabinet's ECC (Economic 
Coordination Committee) approved the plan to use biofuel as an alternative fuel in its hearing. The canon's critical ends will be as follows:

- The Petroleum and Natural Resources Ministry can establish fuel standards of quality for B-100 (spiffy biofuel) and mix up to B-20 (20\% biodiesel/80\% diesel mixture).

- $\mathrm{AEDB}$ is perhaps the main preparation and support agency for the nationwide biofuel scheme.

- $\quad$ Oil Marketing Companies (OMCs) will be sourcing biofuel (B-100) from biodiesel manufacturers and, at the time of selling, providing this processed diesel-mixed biodiesel (getting started with B-5).

- The gradual introduction of biofuel combined with petroleum fuel will reach a minimum of $5 \%$ by volume of a state's total diesel use by 2015 , and $10 \%$ by 2025 .

Pakistan State Oil (PSO) arranged the biodiesel pilot scheme in 2010, with the involvement of the AEDB and the Pak Agricultural Research Council. The progress of the 2012 pilot plant led to an oil marketing firm's blend of biofuel in 2013 [69]. Pakistan's long-term comprehensive energy strategy accounts for four core values: availability, affordability, sustainability, and responsibility (use). As part of the overall strategy, the alternate and renewable energy) (ARE) 2019 Strategy aims to create an effective, reliable, safe, accessible, productive, and environmentally safe power grid, while encouraging the indigenization of sources of energy and the growth of local production potential in these technologies.

ARET's key goals for 2019 are as follows:

- ARET energy projects guarantee quick routes and open growth.

- To protect the atmosphere by raising the proportion of "carbon" resources in the global energy mixture.

- Encouraging and ensuring local capital is exploited.

- Providing the minimum expense of producing energy while considering certain restrictions.

- Encouraging private industry expenditure, thus maintaining reasonable return rates.

Different goals are established under this Framework which can be changed occasionally through administrative intervention instead of legislative reform. Currently, the GOP also set goals of at minimum $20 \%$ renewable power capacity generation by 2025 , as well as at least $30 \%$ by 2030 ( 20 by 25 and 30 by 30 ). To accomplish such goals, the GOP must obtain a higher proportion of additional power through the alternate and renewable energy (ARE) Policy 2019, considering the limitations of baseload, variance production criteria, and alternate and renewable energy technologies (ARET's) alternative options that are like baseload power variables [70].

\subsection{Policy Suggestions on Biodiesel}

Pakistan seems to have a huge potential for generating biodiesel if the resources are being used in a sustainable manner and action is taken in the right direction. As per a report focused on evaluating the Environmental Kuznets Curve (EKC) assumption to evaluate the ability of renewables in Pakistan data collected spanning the duration from 1970 to 2012, militant enthusiasm for EKC has been identified. Renewable electricity plays a major role in lowering $\mathrm{CO}_{2}$ pollution, and current non-renewable activities are the key contributors to $\mathrm{CO}_{2}$ pollution, as per previous research. The policy will also promote the extension of investment in renewable energy initiatives to offset and alleviate the effects of climate change and global warming [71]. The major economic dependency on agriculture in Pakistan affects $70 \%$ of the country's citizens. People's living conditions may be improved by planting oil seed plants. Less expenditure is expected in a mini-scale production facility which can aid in biofuel development [72]. The barren land areas that can solve water scarcity problems and soil salinity are being used for the development of oil plants. Expanding energy plants can be advantageous for the welfare of farmworkers and the state's economy. The use of specific technology rather than several technologies is needed for effective commercially and mainstream biomass energy production settlements in 
Pakistan's rural locations [29]. Pakistan has been one of the fast-growing power economies in the world during the last 20 years due to the increasing population and rising per capita energy use, rapid urbanization, and sound economic development [73].

Pakistan's main contributors to a power crisis are strong electricity demand, poor energy source expertise, rising oil import prices, increasing manufacturing requirements, and accelerated demographic development. Electrical power requirements for homes and factories have risen due to fast demographic development. The world's rural sector, which accounts for around $62 \%$ of an overall world demographic, is largely reliant on non-commercial assets [74]. The world's economic recession has arisen over the last five years due to an unforeseen energy crisis. Lower output along with higher losses stems from a lack of modern knowledge when using energy sources [72]. The long-term energy problems confronted can be resolved by leveraging alternative energy sources in developed countries. Expanding the resources available and finding new outlets is necessary to keep those assets competitive. The environmental effect is indirect due to poor productivity in extra carbon emissions [75].

In February 2008, the Ministry for Water and Power in Pakistan issued guidelines which the Cabinet's Economic Coordinating Committee considers helpful for the use of biofuels as an alternate fuel. The plan is accepted and as per this overview, the Water and Power Ministry and Alternative Energy Development Board (AEDB) will organize the National Biodiesel System to include the services. To fulfill the criteria for consistency in fuel in accordance with the Ministry of Petroleum and Natural Resources, up to 5\% of the total quantity should be mixed with biofuel by 2015 and $10 \%$ by $2025[63,76]$. To guarantee biodiesel's price competitiveness with Petroleum Diesel OGRA, the price process of different biodiesel variants (B-5, B-10, etc.) should be liable. In addition to making the usage of biodiesel mandatory for public-sector automobiles operating on diesel at such a cost decided by OGRA, the government must provide biodiesel manufacturers with incentives for buying back. Manufactured plants, supplies, machines, and similar products are excluded from customs duties and taxes used in biofuel development [77].

As with the ramifications of solar energy, the bioenergy industry still suffers from a shortage of financing, adequate policymaking, and execution. Similarly, AEDB, Pakistan's Higher Education Commission (HEC), Pakistan's Ministry of Climate Change (MOCC), Pakistan's Environmental protection Agency (Pak-EPA), and PSO will take steps to cooperate with universities and institutes and distribute funding for bioenergy development and research. They need to evaluate and update the Mid-Term Policy (MTP), identify the inefficiencies in meeting the standards set in 2015, and create a detailed plan to accomplish $10 \%$ (B-10) to $20 \%$ (B-20) biofuel blends in diesel in 2025 at PSO station in Pakistan, with biofuel that will conform with ASTM requirements $[71,78]$. For meeting energy needs and discovering sustainable and anti-conventional power options, numerous problems such as analysis, growth, promotion, network creation, decentralized model of the power distribution system, business development, education, outreach initiatives, public perception, incentives, policy involvement, technology transition, acceptance, tracking, and assessment should be recognized, and there also needs to be a clear framework for consistently tracking and incorporating them at the state level [79].

\subsection{Biodiesel Benefits and Drawbacks}

Biodiesel has certain benefits and deficiencies that are summarized in Table 2 as follows. 
Table 2. Review of benefits and deficiencies of biodiesel $[1,80]$.

\begin{tabular}{|c|c|c|}
\hline No. & Benefits & Deficiencies \\
\hline 1 & $\begin{array}{l}\text { Biodiesel could boost the efficiency of an engine } \\
\text { because it has a Cetane amount of above } 100 . \\
\text { Biodiesel seems to be more cost-effective than }\end{array}$ & Injection smelting on the piston and motor side. \\
\hline 2 & gasoline since it is locally sourced. & Biodiesel is not compatible with diesel or gasoline. \\
\hline 3 & $\begin{array}{l}\text { It could be used without requiring extra } \\
\text { lubricant, except for diesel motors, due to } \\
\text { biodiesel's consistency and pureness. }\end{array}$ & $\begin{array}{l}\text { During cold conditions, greater pouring and clouds stage and } \\
\text { oil freezing, triggering a cool weather launch. }\end{array}$ \\
\hline 4 & $\begin{array}{l}\text { Biodiesel releases fewer toxins than fossil fuels, } \\
\text { such as } \mathrm{CO}, \mathrm{HC}, \mathrm{CO}_{2}, \mathrm{PM} \text {, and } \mathrm{SO}_{2} \text {. }\end{array}$ & It produces more NOx than diesel fuel. \\
\hline 5 & $\begin{array}{l}\text { Biodiesel has a tremendous capacity to promote } \\
\text { effective rural growth and an electricity } \\
\text { protection approach. }\end{array}$ & $\begin{array}{l}\text { The higher viscosity during long-term service induces clogging } \\
\text { growth, injector deposition forming, filter plugging, rows and } \\
\text { injectors, loop clinging, and inconsistency with traditional } \\
\text { moisturizing oils. }\end{array}$ \\
\hline 6 & No motor alteration is needed until B-20. & $\begin{array}{l}\text { Biodiesel reduces strength and motor rpm. Biodiesels drop } \\
\text { about } 5 \% \text { on average relative to oil at level load. }\end{array}$ \\
\hline 7 & $\begin{array}{c}\text { Being less harmful, more degradable, and } \\
\text { possessing a low spark level, it is easier to treat. }\end{array}$ & Carbon sits on pistons and engine heads. \\
\hline 8 & $\begin{array}{c}\text { Biodiesel production is better than fossil fuels, } \\
\text { and requires little time. }\end{array}$ & Biodiesel has had an acidic quality to the brass and copper. \\
\hline 9 & Greater performance in combustion. & Biodiesel induces unnecessary damage to engines. \\
\hline 10 & $\begin{array}{l}\text { It is inflammable and non-poisonous, decreasing } \\
\text { the exhaust pipe, noticeable fumes, toxic vapors, } \\
\text { and bad smells. }\end{array}$ & Biodiesel depletion during preservation for longer periods. \\
\hline 11 & $\begin{array}{l}\text { Despite the sulfur level, flame stage, aromatic } \\
\text { quality, and biodegradability of biodiesel are } \\
\text { higher than diesel fuel. }\end{array}$ & $\begin{array}{l}\text { Because of the chemical composition and massive molecular } \\
\text { mass of plant oils, the large viscosity (around } 12 \text { times higher } \\
\text { than diesel fuel) creates issues in the atomization, pumping, } \\
\text { and combustion of a diesel engine's injector structures. }\end{array}$ \\
\hline
\end{tabular}

\subsection{Biodiesel Sustainability}

The idea of sustainable development has been included in the United Nations Commission on the Environment's 1987 study entitled Our Shared Future, organized by Gro Harlem Brundtland. In this study, sustainability was described as addressing the needs of today's generation without undermining future generations' needs. The growing concern in spreading biofuel output on a worldwide scale, in addition to the shortage of traditional fossil fuels, their increasing pollutant pollution, their growing costs, and the need to develop biodiesel sustainability and qualification requirements, has been established globally [81,82]. Biodiesel is used as a way out of misery for developed countries. Besides, biodiesel will offer new opportunities for innovation in agriculture research and production, and provide farmers with an income stream [83] and promote connections to already non-existing food stores [84]. Biodiesel usage will render any country self-dependent to a certain degree, but it is still far behind in making a substantial change in crude oil imports, which is required nowadays.

The biodiesel sustainability standards were drawn mainly from current standards established by the Sustainable Biofuels Roundtable (RSB). The following are some principles of these concepts $[85,86]$ :

- Biodiesel output shall lead to the growth of local communities in economic and social terms.

- Biodiesel development shall prevent adverse impacts of higher ecological importance on habitats, communities, and regions.

- Biodiesel shall lead to climate change mitigation by substantially reducing greenhouse gas pollution from the lifecycle relative to fossil fuels. Producers will continue to work to boost the use of biodiesels. 
- The biodiesel sector shall incorporate management processes in the supply chain that preserve and aim to enhance habitats, areas with high ecological value, and the efficiency of natural resources, including land, climate, and water.

- The development of biodiesel would aim to enhance food protection.

- The development of biodiesel shall own the rights to natural resources, including water and land.

- Biodiesel's development shall foster human and civil rights and maintain healthy and fair work conditions.

Achten et al. [87] conducted a qualitative assessment of Jatropha production's future feasibility, focused on the environmental, economic, and social aspects, and decided that the agriculture is viable when conducted in barren or depleted fields but not where productive regions are used that could be used to plant more lucrative grain or other crops.

\subsection{Perspectives on Biofuels in Pakistan}

Pakistan is a country dependent on agriculture, contributing to $19.31 \%$ of the GDP. The country's population is over 220 million and has an annual rate of growth of $2.67 \%$. In 2050, it will be the fourth largest nation in terms of population, as projected by Pakistan's 2010 economic survey [88]. Fuel poverty has risen in Pakistan because of Pakistan's low per citizen GDP (2600 US\$) [2]. Due to sudden increases in fuel costs, commodities have been out of reach for most of its citizens. Due to this, the unsustainability condition in the social structure is growing [89]. A country's economy and strong stability are related to the supply of energy, and its success relies on energy utilization per capita. Therefore, in this case, Pakistan would seem like a nation with an energy shortage [74,75]. In the past, numerous steps have been taken to encourage renewable energy in Pakistan. However, their outcomes are as yet unknown due to corruption and a complete lack of policy. The Appropriate Technology Council of Pakistan (PCAT) was founded in 1975 to build and improve electricity, food markets, homes, solar cookers, and irrigation for health improvements [90].

The PCRET (Pakistan Council for Renewable Energy Technology) was founded in 2001 to boost research and development in the inexhaustible energy sector in Pakistan. PCRET's key goals are to build carbon-free technology solutions for a sustainable world. PCRET carries out research programs in solar photovoltaics, biogas, micro-hydro, wind, and solar-thermal energy. PCRET's research and development projects primarily include solar dryers, solar-thermal laboratory, photovoltaic goods processing, solar-powered, photovoltaic lighting, and electricity boot camps in Pakistan's rural areas. Similarly, the AEDB (Alternative Energy Development Board), founded in 2003, already works in Pakistan to boost alternative fuels that can help to reduce gas emissions of the greenhouse, and advancement of sustainable energies through various projects also acknowledged by the International Solar Energy Society (ISES) on an international level [79]. In Pakistan, energy demand has been significantly increased compared with its existing supplies. Due to a substantial population increase, Pakistan has been experiencing an energy shortage and growing energy demands over the last few years. There is no attempt to increase energy supply to fulfill the energy demands that expand the energy supply and usage differences every year $[75,91]$.

According to an estimate, the country's energy demand will increase three times before 2050. However, the availability is not sufficient in terms of the market. Gas and oil reserves are inadequate in Pakistan, which could only satisfy the demands over the next 10 to 19 years, respectively. Due to the worldwide trend for the last five years, fossil fuel prices have risen drastically, and Pakistan's domestic electricity and energy production heavily depends on fossil fuels [92,93]. By importing oil, approximately $80 \%$ of the energy needs of Pakistan are achieved. Oil/petroleum products, gas, and hydroelectricity are the main sources of energy, while limited amounts of resources are exchanged by renewable energy and nuclear power. The industrial energy market holds 50.3\% gas, $29.8 \%$ oil, $11.01 \%$ hydro, 7.6\% coal, and 1.2\% nuclear energy, according to figures from 2005-2006 [94], as 
the collapse of Pakistan's power supply makes clear. Thermal power plants account for $64 \%$ of overall electricity usage, while hydroelectric power accounts for around $33 \%$, and nuclear power accounts for around $2.4 \%$ of total energy shares. It requires $44.2 \%$ of the domestic energy market. Industry uses $31.1 \%$, while farming uses $14.3 \%$ of the country's overall energy supply [95].

The dramatic rise in energy rates has been a major issue for the average Pakistani citizen. For reference, the 2007 petrol price was $\$ 0.9$ USD per liter. Pakistan imported petroleum products in the fiscal year of 2006 that cost roughly USD 3.1 billion. It seemed to reflect approximately $85 \%$ of the global oil usage. Pakistan experienced an overall power deficit of $40 \%$ in 2008, equivalent to more than 4000 Megawatts. To fill the current energy deficit among electricity demand and supply, concrete and practical steps to improve Pakistan's energy generation capacity are desperately required [73]. Shifting the movement toward ethanol fuel would certainly save the country's substantial foreign exchange. Mixing 10\% ethanol with fuel will save \$300 million in foreign currency. Pakistan's Hydrocarbon Development Institute (HDIP) and Pakistan State Oil (PSO) also initiated a research project to test the usefulness of blend fuel to address the country's energy shortages [74,78].

Pakistan's geographical position is unique and an ideal atmosphere, and there are several opportunities for producing wind and solar energy. However, the solar and wind power production is currently quite small, caused by a lack of government policies. Biomass energy generation is low due to traditional un-scientific activities carried out primarily in rural areas. The most widely used household fuels are farm waste, livestock waste, and tree wood for warming and cooking purposes. Large mining resources can play an important role in solving the energy problem; however, they are not utilized. Production of modern hydropower generation schemes has risen over the past two decades, though unfortunately, nuclear power still contributes to $3 \%$ of the country's overall electricity supply $[29,96]$. Biofuels may be a better choice for meeting Pakistan's energy needs. Furthermore, biofuels' capacity for production and use has also not been tapped. The development of commercial biofuels did not gain much publicity.

The use of sugar from molasses could produce bioethanol. Biodiesel may be a possible source of biofuel in Pakistan [93,97]. In Pakistan, at least 5\% of biodiesel was required as a blending fuel by 2015. In Pakistan, food crops cannot rely on the biodiesel industry. Plant oil is one possible source for biodiesel output [98]. Pakistan State Oil (PSO) started to work on biofuels, with a concentration on biodiesel. PSO has grown Jatropha Curcas (a non-edible and promising energy source) plants at the PSO place near Sindh. Due to its specific characteristics, PSO picked Jatropha Curcas as a prospective plant choice for biodiesel, and extensive research work was carried out by countries such as Malaysia, India, Brazil, the USA, and China for the same purpose. About 1 million acres of marginal/barren/wasteland is needed for Jatropha planting to generate a $10 \%$ biodiesel blend [29].

\section{Jatropha Curcas}

\subsection{Horticultural Details of Jatropha Curcas}

J. Curcas is a small and medium sized fern tree, rising to around 5-7 $\mathrm{m}$ tall, belonging to the Euphorbiaceae genus [37,42,99-106], consisting of approximately 800 species, around 321 genera. Many plants of global economic importance come from this family, as follows [107]:

- Physic nut

- Roots: esculenta Manihot (cassava)

- Chinese sebiferum (Sapium sebiferum); J. Linn Curcas

- Hydrocarbon: spp euphorbia

- H. brasiliensis: Rubber

- Oils: linn ricinus communis (castor bean); spp aleurites (Tung Tree)

- Nuts: The orinocense caryodendron tacay nut

- Medical: croton spp.; jatropha spp 
- Vegetables: Sauropus androgynus (katuk)

Jatropha is an herb immune to famine, with a lifespan of around fifty years $[37,106,108,109]$. It is also called physic nut and Ratanjayot $[38,42,102,108]$. It may grow within the forest, parched and semi-parched $[109,110]$. The plants grow a large flower stalk and initially four deep, superficial roots. The tapering root can strengthen the ground toward mudslides, while the deeper roots are believed to avoid and monitor air or water-borne soil degradation, but this ability is not being scientifically examined. The leaf is flat, with 4-6 lobes, and is about $10-15 \mathrm{~cm}$ long, and wide. The plant is polygamous, so there are bisexual plants in the marginal leaf buds. The proportion of female to male plants varies between 1:13 and 1:29 and reduces with plant age. Usually, JCL flowers in the rainy season once per year. JCL grows almost year-round in chronically moist areas or under deluge conditions. The black seeds with certain authenticity produce contaminants, such as phytates, phorbol esters, lectins, trypsin agonists, and curcin, to prevent detoxification of seeds, oil, and seed cake [100,111,112].

J. Curcas may grow from 250 to above $1200 \mathrm{~mm}$ per year under a wide variety of rainfall climates [101,113]. The growing temperature is $20-26^{\circ} \mathrm{C}$, and these plants can also adjust between 5.0 to $6.5 \mathrm{pH}$, fertile soil, not stagnant, and decent drainage [114]. The J. Curcas plant grows in well-drained fields with good air circulation and is well-suited to little land with a lower nutritional quality, and it sheds its leaves during the hot season [99,101]. Planting spaces of 2 by $2 \mathrm{~m}, 2.5$ by $2.5 \mathrm{~m}$, and 3 by $3 \mathrm{~m}$ have been stated to be enough and to produce greater fruit outputs [105]. It grows fruit from the second year of creation, and from the fourth or fifth year onwards, the growth stabilizes economic production. The plant is a kernel, with 3 seeds in each. It yields approximately $2-4 \mathrm{~kg} / \mathrm{seed} / \mathrm{plant} /$ annually. The yields in bad soils were stated to be $1 \mathrm{~kg} / \mathrm{sow} / \mathrm{plant} /$ annually [115]. J. Curcas oil outputs are estimated at $1590 \mathrm{~kg} / \mathrm{ha}[38,104,116,117]$.

\subsection{Jatropha Curcas Growth and Applications}

J. Curcas will generate $2000 \mathrm{~L} /$ ha of oil annually [118]. JCL oil is transesterified primarily into (m)ethyl esters (biofuels) and glycerol [43]. Currently, J. Curcas fuel development and use are no longer restricted to a geographical area or just a small range of final products, and significant amounts of J. Curcas fuel are used worldwide, as components in various goods produced by a broad number of sectors. J. Curcas was discovered to have been ideal in the oleochemical industries as a non-edible vegetable oil raw material (biofuels, cosmetics, soap, fatty acids, kerosene, fat nitrogen compounds, and cleaning products, etc.) $[42,118,119]$. The J. Curcas oil industry was developed over the years to provide J. Curcas oil as well as its associated products [107]. Figure 10 illustrates several major J. Curcas usages.

The J. Curcas plant was noticed to be ideal in several cultures for usage in different facets. It is typically grown across Indonesia's farm fields as a live fence, as cows or goats do not consume it. It can also be sliced or clipped to the required size. Aside from the use of J. Curcas oil as a biofuel, biocides (herbicide, molluscicide, nematicide, and pesticide) and soap may also be generated using the oil [120]. 


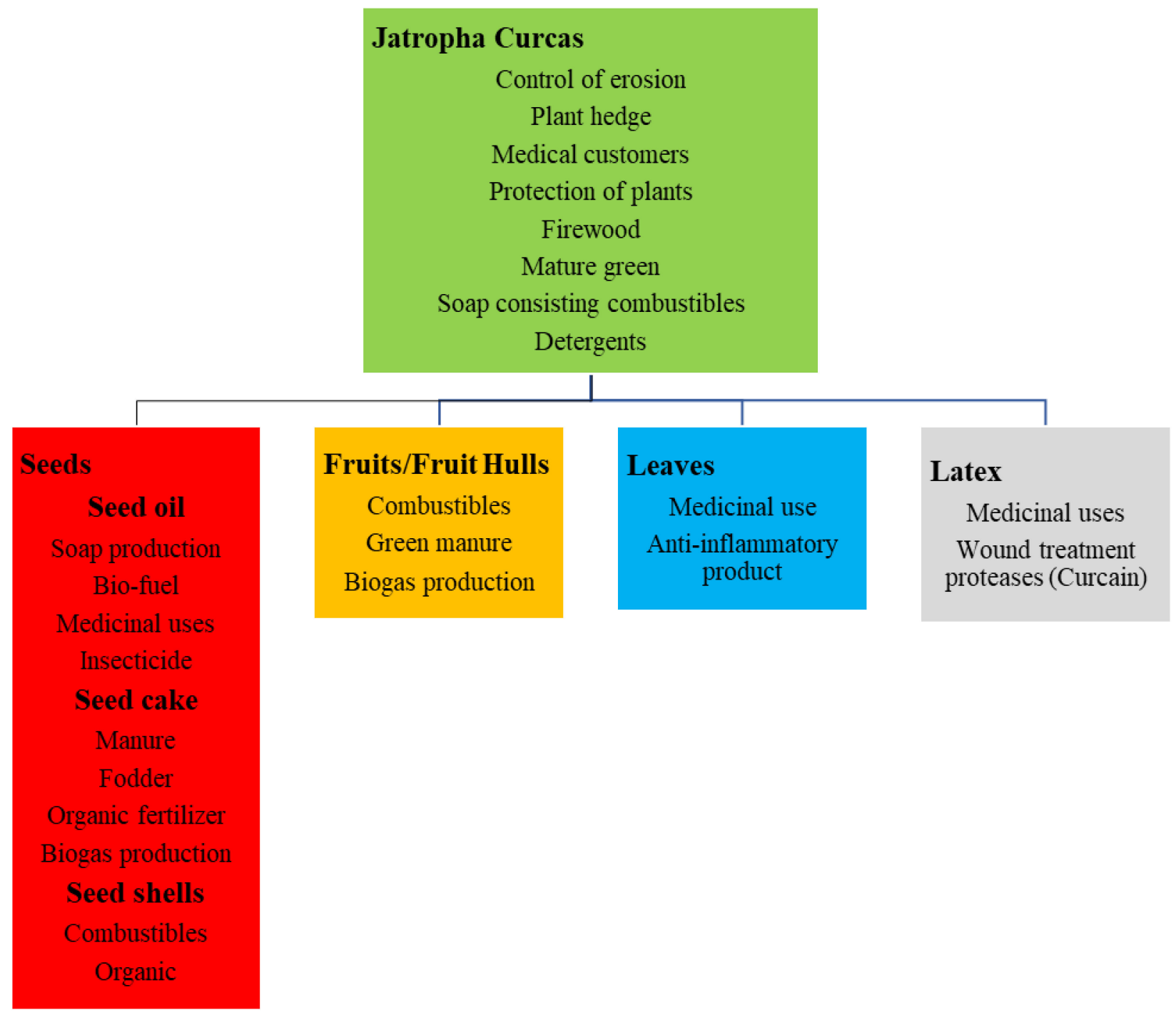

Figure 10. A few essential Jatropha Curcas usages [106,107,120].

\subsection{Jatropha Curcas Qualities and Properties}

The properties of raw J. Curcas oil (CJCO) differ according to the area in which it was produced. The actual quantity of fuel collected from a provided seed sample relies on the nature of the raw material and the extracting process. J. Curcas kernel oil content was observed to have been greater than sunflower oil, soya, and palm kernels, 33.33\%, $18.35 \%$, and $44.6 \%$ respectively [121], while in several other sources, the oil content of the J. Curcas kernels was $63.16 \%$ and $66.4 \%$ [119,122]. The specifications that are chosen and set to determine biodiesel efficiency can be split into two classes. Each class includes basic criteria that are often used for mineral oil-based fuel, such as physical and chemical characteristics. The other category defines the chemical structure and cleanliness of methyl esters of fatty acids [123]. Table 3 describes the physicochemical characteristics of boorish J. Curcas fuel. Moreover, some properties of J. Curcas in Pakistan is shown in Table 4. 
Table 3. Physicochemical characteristics of crude Jatropha Curcas oil $[120,124,125]$.

\begin{tabular}{cc}
\hline Parameters & Jatropha Curcas Oil \\
\hline Density at $15^{\circ} \mathrm{C}\left(\mathrm{g} / \mathrm{cm}^{3}\right)$ & 0.920 \\
Flashpoint $\left({ }^{\circ} \mathrm{C}\right)$ & 240 \\
Cloud point $\left({ }^{\circ} \mathrm{C}\right)$ & $9 \pm 1$ \\
Cetane number & 38 \\
Viscosity at $30^{\circ} \mathrm{C}(\mathrm{cSt})$ & $52 \mathrm{cSt}$ \\
Pour point $\left({ }^{\circ} \mathrm{C}\right)$ & $4 \pm 1$ \\
Fire point $\left({ }^{\circ} \mathrm{C}\right)$ & $274 \pm 3$ \\
Caloric value $(\mathrm{MJ} / \mathrm{kg})$ & 38.20 \\
Conradson carbon residue $(\% w / w)$ & $0.8 \pm 0.1$ \\
Oxygen $(\% w / w)$ & 11.06 \\
Carbon $(\% w / w)$ & 76.11 \\
Sulfur $(\% w / w)$ & 0 \\
Nitrogen $(\% w / w)$ & 0 \\
Hydrogen $(\% w / w)$ & 10.52 \\
Iodine $\mathrm{No}$. & 0.92 \\
Ash content $(\% w / w)$ & $94 \pm 0.0$ \\
Saponification value & 0.03 \\
Monoglycerides & 198.00 \\
Triglycerides $(\mathrm{m} / \mathrm{m})$ & Not distinguished \\
Diglycerides & $97.3 \%$ \\
Calcium $(\mathrm{mg} / \mathrm{kg})$ & $2.7 \%$ \\
Iron $(\mathrm{mg} / \mathrm{kg})$ & 56 \\
Water $(\mathrm{m} / \mathrm{m})$ & 2.4 \\
Magnesium $(\mathrm{mg} / \mathrm{kg})$ & $0.07 \%$ \\
Phosphorus $(\mathrm{mg} / \mathrm{kg})$ & 103 \\
Neutralization number $(\mathrm{mg} \mathrm{KOHg})$ & 290 \\
\hline &
\end{tabular}

Table 4. Tested by Faisalabad [126] and PSO [29], domestic biodiesel's important characteristics from Jatropha and highspeed diesel.

\begin{tabular}{cccccc}
\hline $\begin{array}{c}\text { Parameters } \\
\text { Density at } 2{ }^{\circ} \mathrm{C}\end{array}$ & $\begin{array}{c}\text { High-Speed Diesel } \\
\text { (PSO) }\end{array}$ & B-10 (PSO) & B-100 (PSO) & B-100 (Faisalabad) & Test Method \\
$\left(\mathrm{g} / \mathrm{cm}^{3}\right)$ & 0.83 & 0.8522 & 0.8816 & 0.88 & ASTM D 1298 \\
Kinematic & 2.73 & 4.19 & 4.38 & 4.8 & ASTM D 445 \\
Viscosity $(\mathrm{cSt})$ & 46 & 53 & 47 & - & ASTM D 976 \\
Cetane index & 37 & 90 & 140 & - & ASTM D 93 \\
Flash point $\left({ }^{\circ} \mathrm{C}\right)$ & 19,528 & 19,233 & 17,162 & ASTM D 240 \\
Calorific value & & & & \\
$($ Btu $/ \mathrm{lb})$ & & & & & \\
\hline
\end{tabular}

The main fatty acids in JCL seed oil are linoleic, oleic, stearic, and palmitic acids. Oleic acid recorded the largest compositional proportion, followed by linoleic acid $[37,100,102,108,110,119,127,128]$. Fatty acids' formation of J. Curcas oil is provided in Table 5. 
Table 5. Fatty acid's formation of J. Curcas oil [114,120,127,129].

\begin{tabular}{cccc}
\hline Fatty Acid & Structure a & Formula & $\begin{array}{c}\text { Composition } \\
\text { (wt.\%) }\end{array}$ \\
\hline Myristic & $(14: 0)$ & $\mathrm{C}_{14} \mathrm{H}_{28} \mathrm{O}_{2}$ & $0-0.1$ \\
Palmitoleic & $(16: 1)$ & $\mathrm{C}_{16} \mathrm{H}_{16} \mathrm{O}_{2}$ & $0-1.3$ \\
Oleic & $(18: 1)$ & $\mathrm{C}_{18} \mathrm{H}_{34} \mathrm{O}_{2}$ & $34.3-45.8$ \\
Linolenic & $(18: 3)$ & $\mathrm{C}_{18} \mathrm{H}_{32} \mathrm{O}_{2}$ & $0-0.3$ \\
Behenatic & $(22: 0)$ & $\mathrm{C}_{22} \mathrm{H}_{44} \mathrm{O}_{2}$ & $0-0.2$ \\
Palmitic & $(16: 0)$ & $\mathrm{C}_{16} \mathrm{H}_{32} \mathrm{O}_{2}$ & $14.1-15.3$ \\
Stearic & $(18: 0)$ & $\mathrm{C}_{18} \mathrm{H}_{36} \mathrm{O}_{2}$ & $3.7-9.8$ \\
Linoleic & $(18: 2)$ & $\mathrm{C}_{18} \mathrm{H}_{32} \mathrm{O}_{2}$ & $29.0-44.2$ \\
Arachidic & $(20: 0)$ & $\mathrm{C}_{20} \mathrm{H}_{40} \mathrm{O}_{2}$ & $0-0.3$ \\
\hline a Carbon in the chain: double bonds. & &
\end{tabular}

a Carbon in the chain: double bonds.

Since the mechanical stickiness of J. Curcas oil is quite strong, the friction coefficient of J. Curcas oil for use in biodiesel must be decreased [85]. The large viscosity of J. Curcas oil frequently contributes to compliance issues, including carbon accumulation, fuel ring trapping, oil thickening, and gelatinizing due to vegetable oils. The smoother flow of oil in the motor can also be influenced by the increased viscosity of J. Curcas oil. Varied methods such as preheating, drying, transesterification of ultrasonic methanol, and supercooled methanol are being used to reduce viscosity to render it suitable for motor operations [130-132]. After transesterification, the kinematic viscosity of raw J. Curcas fuel could be reduced by around $82 \%$ and corresponds to $4.8 \mathrm{~mm}^{2} / \mathrm{s}[87,133]$. J. Curcas fuel's flashpoint is higher relative to fossil fuels. Jatropha fuel has many benefits over diesel, including increased protection in preparation, processing, and transportation, due to its increased ignition point. The high flashpoint may, therefore, affect the motor's initial start issue [132].

Like biodiesel derived from plant oils, including palm oil, J. Curcas fuel has a low pouring level. Therefore, it can be utilized in countries with four certain seasons [134]. The iodine content is an indicator of oils' and fats' unsaturation. High iodine content indicates a greater unsaturation of oils and fats [135]. The iodine quality of JCL fuel reached $101 \mathrm{gl}_{2} / 100 \mathrm{~g}$, where the normal iodine quality for diesel is less than 120 for European standard $14214 \mathrm{EN}$. The restriction of fatty acids is also important since the heat of highly unsaturated fatty acids resulted in glyceride polymerizing. It may contribute to development of deposit accounts, oil decay, and the creation of dense effluent in the motor tank [119]. Table 6 describes the characteristics of JCL fuel and JCL methyl esters with all the requirements of ASTM D6751 and EN 14214. Table 7 demonstrates the physicochemical characteristics of JCL fuel in comparison to diesel as well as its variants.

Table 6. Characteristic comparison of diesel, Jatropha methyl esters, Jatropha oil, ASTM D 6751, and EN 14214 specifications $[16,42,120]$.

\begin{tabular}{|c|c|c|c|c|c|}
\hline Properties & Diesel & JME & Jatropha Oil & ASTM D6751 & EN 14214 \\
\hline Density at $15^{\circ} \mathrm{C}\left(\mathrm{kg} / \mathrm{m}^{3}\right)$ & 850 & 879 & 918 & $875-900$ & 860-900 \\
\hline Acid value (mg KOH/g) & 0.35 & 0.24 & 11 & 0.5 (Maximum) & 0.5 (Maximum) \\
\hline Sulfated ash $\left(\mathrm{wt}^{\mathrm{o}} \%\right)$ & - & 0.014 & - & 0.02 & 0.02 \\
\hline Kinematic viscosity at $40{ }^{\circ} \mathrm{C}(\mathrm{cSt})$ & 2.6 & 4.84 & 35.4 & $1.9-6.0$ & $3.5-5.0$ \\
\hline Cetane number & 46 & 51 & 23 & 47 (Minimum) & 51 (Maximum) \\
\hline Flashpoint ${ }^{\circ} \mathrm{C}$ & 70 & 191 & 186 & 130 (Maximum) & >101 (Minimum) \\
\hline Iodine number (g/100 g) & - & 86.5 & 101 & - & $<120$ \\
\hline Water $(\mathrm{mg} / \mathrm{kg})$ & 0.02 & 0.16 & 0.05 & 0.05 & 0.05 \\
\hline Calcium (ppm) & - & 6.1 & - & 5 (Maximum) & 5 (Maximum) \\
\hline Conradson carbon residue & 0.17 & 0.025 & 0.3 & $<0.050$ wt. $\%$ & $<0.30 \% \mathrm{~m} / \mathrm{m}$ \\
\hline Free glycerol (wt.\%) & - & 0.015 & - & 0.02 & 0.02 \\
\hline Total glycerol (wt.\%) & - & 0.088 & - & 0.25 & 0.24 \\
\hline Magnesium (ppm) & - & 1.4 & - & 5 (Maximum) & 5 (Maximum) \\
\hline
\end{tabular}


Table 7. Physico-chemical characteristics of JCL fuel and its blends compared to diesel [136].

\begin{tabular}{|c|c|c|c|c|c|}
\hline \multirow[t]{2}{*}{ Properties } & \multicolumn{5}{|c|}{ Fuel Blends } \\
\hline & $100 / 0$ & $80 / 20$ & $50 / 50$ & $97.4 / 2.6$ & 0/100 \\
\hline $\begin{array}{c}\text { Density at } 15{ }^{\circ} \mathrm{C} \\
\left(\mathrm{kg} / \mathrm{m}^{3}\right)\end{array}$ & 866.9 & 876.9 & 891.7 & 868.4 & 917.7 \\
\hline $\begin{array}{c}\text { Pour point }\left({ }^{\circ} \mathrm{C}\right) \\
\text { Kinematic }\end{array}$ & 15 & 12 & 6 & 15 & -3 \\
\hline $\begin{array}{c}\text { viscosity at } 40^{\circ} \mathrm{C} \\
\text { (cSt) }\end{array}$ & 5.7 & 8.2 & 14.6 & 5.9 & 36.9 \\
\hline $\begin{array}{l}\text { Caloric value } \\
(\mathrm{MJ} / \mathrm{kg})\end{array}$ & 45.90 & 44.15 & 43.099 & 45.202 & 42.048 \\
\hline Flashpoint $\left({ }^{\circ} \mathrm{C}\right)$ & 86 & 90 & 94 & 88 & 99 \\
\hline
\end{tabular}

\subsection{The Efficiency of Diesel Engines Using Diesel and Jatropha Methyl Esters}

JCL methyl esters and diesel scientists in several countries worldwide have been studying Jatropha in engines, and have contrasted the engine output tests with those of conventional fuels in identical circumstances. Due to Jatropha's peculiar characteristics, ingestion, alienation, and burning features continue to vary. All such differences in the usage of Jatropha methyl esters in engines may create other problems. The research indicates a major difference in results from the states listed. Many engine output specifications were gathered in this analysis, such as braking strength, fuel usage, brake capacity, torque, thermal brake efficiency, emissions, etc.

\section{Jatropha's Influence on Pakistan's Biofuel Strategies}

Pakistan's initiative to rear and leverage Jatropha crops for biofuel manufacture is nothing short of commendable. Procurement is in progress and is discussed in this section.

\subsection{Jatropha Cropping Status for the Manufacturing of Biofuel}

The presence of Jatropha in the Sindh region has already been recorded [137]. It was recognized as Jamal Ghota, RatanJoth, or Karanga, and has been used in towns and villages for various diseases [138]. Currently, just two trees have persisted and are in the vicinity of Umerkot. Such plants are over 40 years of age and have achieved an elevation of $30 \mathrm{ft}$. It indicates that Jatropha might have been in Pakistan until it became independent [137]. Jatropha was primarily grown by publicly owned entrepreneurs on a micro-scale via several countries' imported seeds [137]. Despite these actions by the private industry, their production grew from about 2 acres in 2005 to over 400 acres in 2008. This rise in JCL agriculture was largely due to an effective movement carried out by the AEDB (Alternative Energy Development Board) $[137,139]$. Many organizations have grown Jatropha nurseries in the private industry at different places in Sindh, Baluchistan, and Punjab. Such a plant sales outlet has been the base in the same areas for various Jatropha fields. In such farmlands, plants' mean age ranges from a few weeks to even more than 18 months [137].

Barely more than 2 acres have been used for the production of Jatropha in 2005. There, however, the private market began to develop nurseries for more agriculture. Nursery managers offered more than 10,000 saplings to multiple cultivators in Punjab, Sindh, and throughout 2006 to transplant into the farmlands. Such nurseries were provided with about 50,000 trees for transplant to different farms in Sindh, and some to the counterpart in Baluchistan in 2007. However, due to increased enthusiasm, knowledge, and potential economic benefits in Jatropha production, Sindh's growers show better outcomes. Thus, more than 200,000 trees were provided in 2008 by different nurseries in Sindh for these transplants owing to the huge-scale abundance of trees on the market [137]. PSO also purchased flowering seeds to expand the nursery in 2008 and implanted 20,000 trees on its farmland [137]. They currently have approximately 10,000-20,000 further trees for these 
transplants $[137,140]$. Moreover, their nurseries across Karachi already had more than 200,000 trees in the first quarter of 2009, and they were prepared to supply more than that if needed [137].

PSO implemented a pilot scheme to leverage JCL crops from its farmland to manufacture biofuels on an extensive scale [141]. The gain predicted for Pakistan was envisioned as follows [141]:

- For a greener atmosphere, 6 million plants would be introduced,

- 500 growers are employed to operate the 5000 -acre plantation,

- From this planting, 24 million $\mathrm{kg}$ of seeds would be generated annually,

- A million liters of biofuel (around PKR 345 million at PKR 48/L of petroleum diesel) would be generated per annum, equal to $17 \mathrm{MT}$ of biofuel in a day.

Other attentive parties, including Karachi's Forest Company and Pak Army, also effectively grow JCL plants in different Sindh regions [69]. In 2010, the Forest Department was able to grow 3000 trees for an exploratory ground in the canton of Malir. PSO provided the Jatropha seeds [137]. The PARC (Agricultural Research Council of Pakistan) and the Canadian firm, Kijani Energy, are involved in large-scale Jatropha production on marginal land for biodiesel [142]. In 2009, Kijani Energy spent approximately USD 150 million in the use of 200,000 acres for jatropha plantations in Tharparker, Umerkot, Sanghar, Cholistan, and Khairpur [143]. The advantage of these practices may be numerous. Jatropha planting is expected to produce at least one worker per acre of tree planting, so the potential effect on farm jobs alone may be enormous. The production cost for biofuel would rely on seed procurement costs, manufactured scale, tax-related government policies, by-product use, seed cakes, and other Jatropha wastes. Nonetheless, when looking at the expense element, it is necessary to look at local job creation, electricity conservation, carbon trading concerns, and foreign exchange savings [137].

Overall, jobs should come from planting, seed processing, oil extraction, biofuel development, and regional distribution [137]. It is reported that job generation from planting and seed collection is 40 person-days/ha/year.

\subsection{Research Activities in Universities}

The Quaid-e-Azam University Islamabad [144-146] and the NED University Karachi [147] were among the universities that announced outcomes from JCL's transesterification oil. Besides, PSO has operated for the same reason at numerous universities in Pakistan [141]. Faisalabad effectively obtained $94 \%$ yields of biofuel from Jatropha oil [126], while PSO yielded greater [141]. Table 4 displays the biofuel Jatropha crude fuel's characteristics, measured by PSO, and separately at Faisalabad. The main gap between the two fuels was that Faisalabad's biodiesel had an ignition point better than PSO. Even though this implied a healthier fuel for the former entity, this also culminated in a low ignitability drawback, thus impacting the fuel benefit. It could have been due to PSO's more sophisticated methods to guarantee the quality of the product owing to a greater intellect of company accountability [29]. NED University was able to test PSO's biofuel in a single-cylinder four-stroke engine (Rotronics). It found that its air pollution outline was better than diesel, canola oil biodiesel, and castor oil biodiesel [147]. NED University investigators have reported that biofuel production from JCL seeds was cheaper than indigenous taramira and castor oil biodiesels (Table 8) [148].

Table 8. Price of producing biodiesel from various non-edible plants [148].

\begin{tabular}{cccc}
\hline No. & Biodiesel & $\begin{array}{c}\text { Cost Per Liter } \\
\text { (USD \$) }\end{array}$ & $\begin{array}{c}\text { Cost Per Liter } \\
\text { (PKR) }\end{array}$ \\
\hline 1 & Jatropha & 1.039 & 155.85 \\
2 & Castor & 1.788 & 268.2 \\
3 & Taramira & 3.044 & 456.6 \\
\hline
\end{tabular}




\subsection{Pakistan State Oil Results}

PSO transformed JCL oil from its plantation to biodiesel, utilizing a state-of-the-art transesterification device [141]. NED University recently performed engine efficiency and pollution testing of PSO's B-10 [147]. The findings explicitly demonstrate that, relative to other indigenous biofuel and natural diesel, Jatropha biodiesel has less effect on the atmosphere. However, its engine output is slightly lower than the mineral equivalent, which is attributed to its poor calorific value compared with mineral fuel [147]. The above problem could be resolved if Pakistani universities perform even more research to boost the calorific value of biodiesel JCL oil.

\section{Current Production of Biodiesel from Jatropha in Pakistan}

The transesterification technology was first designed and evaluated at Sir Syed Engineering and Technology University in Karachi [149]. Within two hours, the overall production potential of biodiesel was $100 \mathrm{~L} /$ batch [149]. It could generate up to $400 \mathrm{~L}$ of biodiesel per day on a full scale, where a $200 \mathrm{~kW}$ generator could use B-100 fuel for 8 h [150]. Like the World Wildlife Fund (WWF) Pakistan, in collaboration with Qarshi Industries, Quaid-e-Azam University (QUEST) in Nawabshah has also been engaged in cultivating Jatropha plantations [151], nevertheless, there are still no studies on any biodiesel development at QUEST in the relevant literature. Islamabad's National University of Science and Technology (NUST) has produced biodiesel from JCL oil [152]. The oil was extracted from plants arising on NUST's internal model farm, covering a field of 15 acres for Jatropha farming. Half a million jatropha plants have now been grown, and this year, at least $4-5$ million plants are anticipated [152]. However, the findings reported by NUST are not described in any academic articles. NED University also grew Jatropha trees in its garden center [153]. Although no seed was collected for transesterification purposes, NED partnered briefly with PSO to perform certain fuel pollution tests of JCL oil in the ignition compression fuel described in the paper [15,47]. NED also organized a regional workshop on biodiesel in which PSO exhibited their truck fueled with Jatropha B-10 [153].

\section{Potential of Jatropha Biodiesel in Pakistan}

In Pakistan, the most suitable areas for the production of Jatropha Curcas are Punjab, Sindh, and some areas of Baluchistan. In these areas, plants' mean age ranges from a few weeks to even more than 18 months [137]. In Punjab, 1.52 million hectares $(3,756,001)$ acres), in Sindh 1.60 million hectares (3,953,686 acres), and in Baluchistan 3.90 million hectares $(9,637,109$ acres) are uncultivated according to 2013-2014 land utilization statistics by the Pakistan Bureau of Statistics [154]. These soils are culturable (a cultivable land but for years not planted) [155]. This area can be used for the cultivation of Jatropha Curcas. The conditions for the Jatropha Curcas plantation are listed in Table 9. From these conditions, the possible shortlisted areas of the Jatropha Curcas plantations in Pakistan are shown in Figure 11.

Approximately $25 \%$ of the total barren land is suitable for Jatropha plantations. The oil yield from Jatropha Curcas is $575 \mathrm{~kg}$ per acre [156]. Therefore, total oil production from Jatropha is 2.93 million tons. The plantation cost per acre for Jatropha Curcas is USD $83[157,158]$. Thus, the total plantation cost for Pakistan is USD 424 million. The imports of petroleum products in Pakistan were 11.84 million tons in 2018-2019, which cost USD 983.3 million [2]. By cultivating the Jatropha Curcas in $25 \%$ of the barren land, Pakistan can cut-off $\sim 2.93$ million tons of imports of petroleum products and save USD $\sim 2$ billion reserves. The main findings of the potential of Jatropha biodiesel in Pakistan are listed in Table 10 and illustrated in Figure 12. 


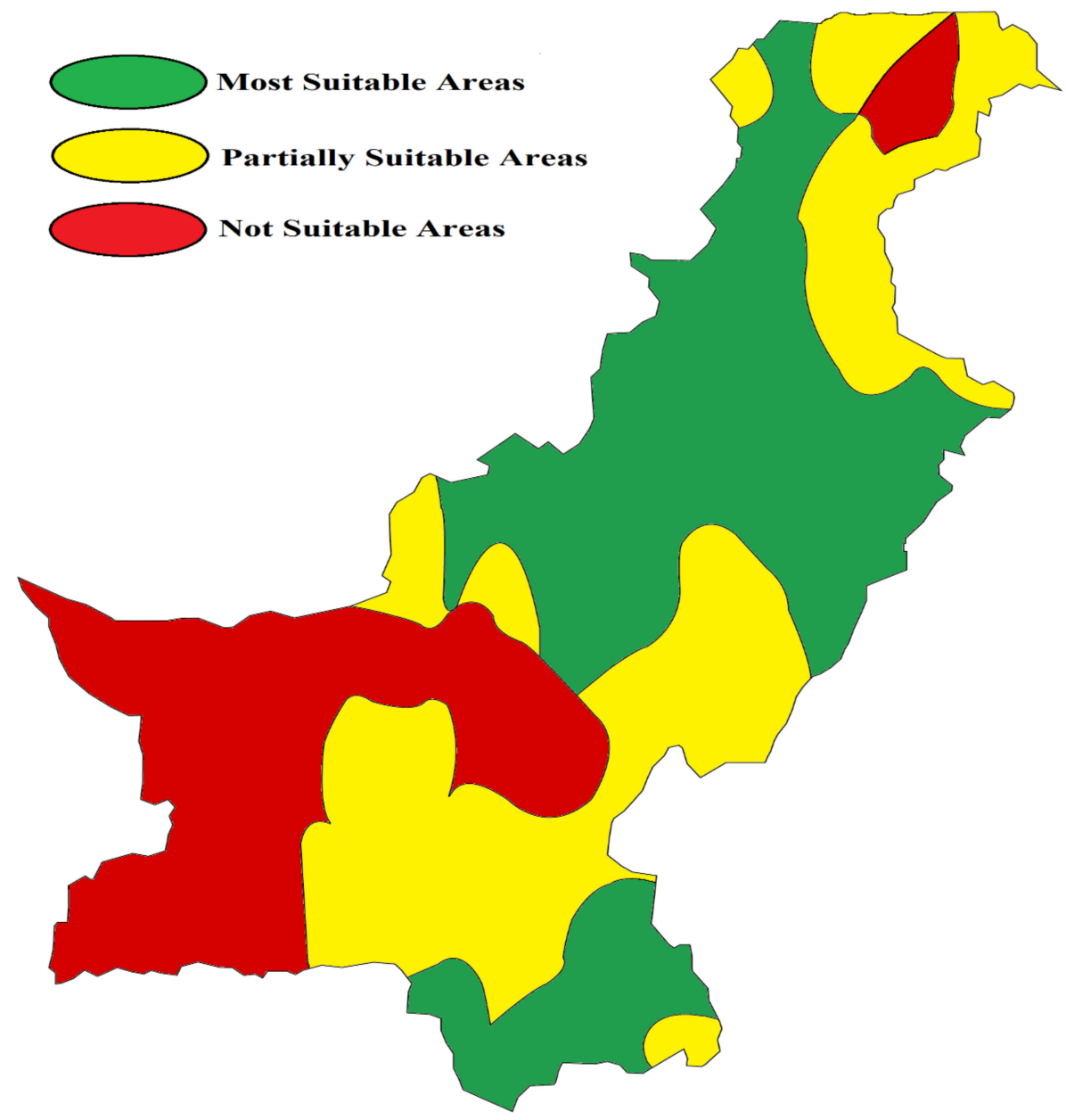

Figure 11. Possible areas of the Jatropha Curcas plantation in Pakistan.

Table 9. Conditions for Jatropha Curcas plantation.

\begin{tabular}{lccc}
\hline Rain Conditions & Land Types & $\begin{array}{c}\text { Temperature } \\
\text { Conditions }\end{array}$ & References \\
\hline Range $250-1200 \mathrm{~mm}$ & Semiarid and Arid Lands & Range $16-28^{\circ} \mathrm{C}$ & {$[112,158-163]$} \\
\hline
\end{tabular}

Table 10. The potential of Jatropha Curcas plantation.

\begin{tabular}{ccc}
\hline Description & Quantity & Reference \\
\hline Total barren land in Pakistan (acre) & $20,435,615.05$ & {$[154]$} \\
Oil yield per acre (kg/acre) & 575 & {$[156]$} \\
Oil content (wt.\%) & 35 & {$[156]$} \\
Jatropha plantation cost (USD/acre) & 83 & {$[157,158]$} \\
Maturity time (months) & 30 minimum & {$[156-158]$} \\
Jatropha oil production (Million ton) & 2.93 & {$[156]$} \\
Total import of petroleum products & 11.84 & {$[2]$} \\
(Million ton) & 424 & {$[155,156]$} \\
Total plantation cost (Million USD) & 9833 & {$[2]$} \\
The total import cost of petroleum & 2 & \\
products (Million USD) & & \\
Saving of reserves (Billion USD) & &
\end{tabular}

Note: 1 USD = 150 PKRs (2018-2019). 


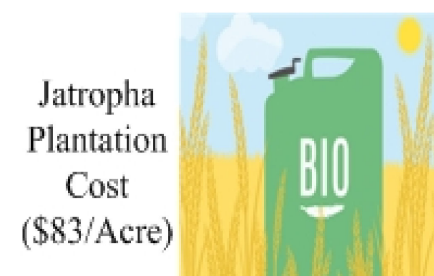

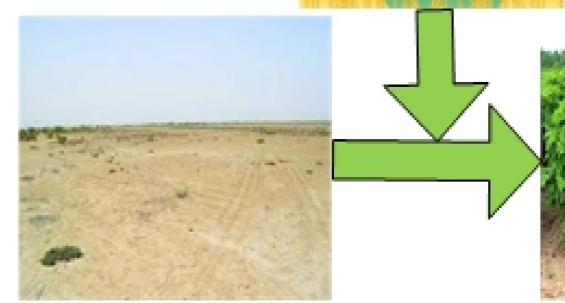

Barren Land $(20,435,615$ acres $)$

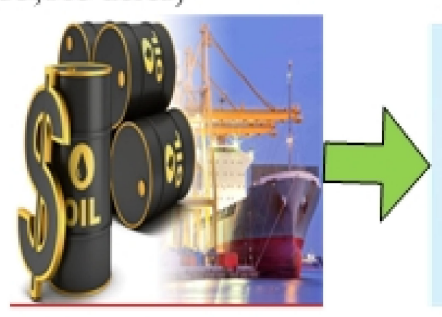

Total Import of Petroleum Products (11.84 Million Tons)

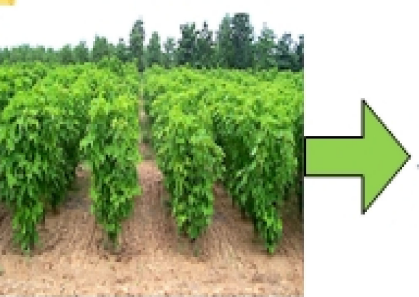

Jatropha Curcas

Plantation
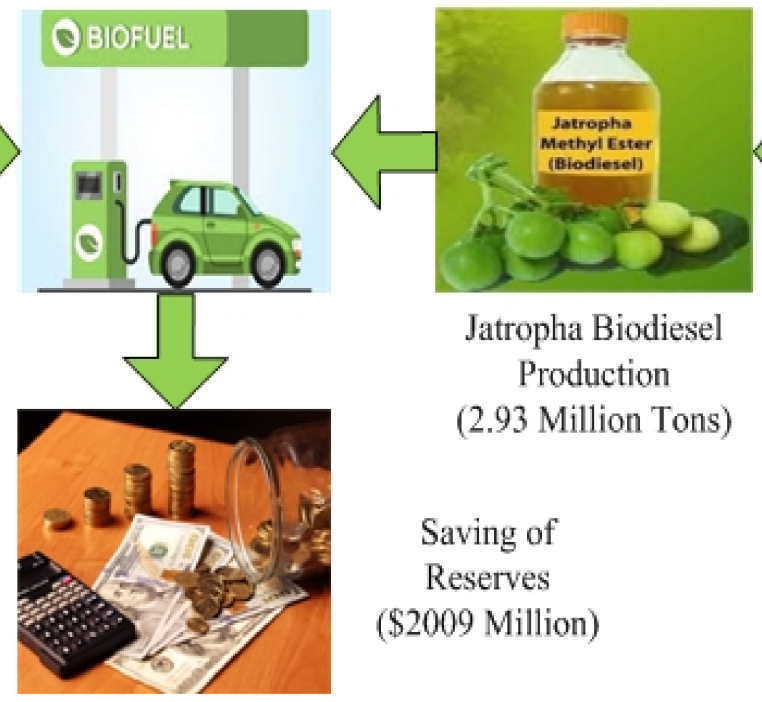

Jatropha Biodiesel

Production

(2.93 Million Tons)

Oil Extraction

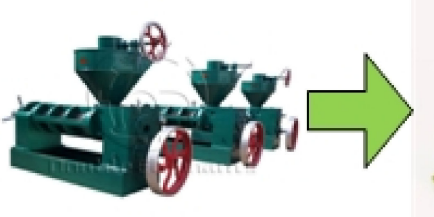

Oil Yield/Acre

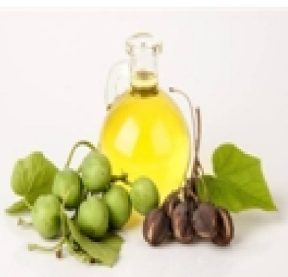

$(575 \mathrm{~kg} /$ acre $)$

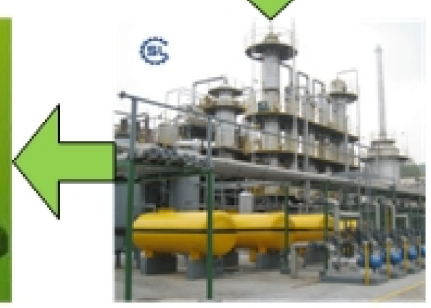

Purification Process

(Oil Content

$35 \mathrm{wt} . \%)$

Figure 12. The potential of Jatropha biodiesel in Pakistan.

\section{Jatropha Curcas Oil Effect as Biodiesel}

Biodiesel use in the agriculture sector faces multiple obstacles and prospects. Various analysis reports suggest that the biodiesel sector would affect food output. Jatropha is, therefore, one of Indonesia's strong options for the biodiesel sector. The following section discusses JCL's environmental, emissions, social, and economic impacts. Furthermore, the political, economic, social, and tech (PEST) analysis is shown in Figure 13.

\subsection{Emission Impacts}

Biodiesel releases fewer pollutants as opposed to fossil fuels, such as $\mathrm{HC}, \mathrm{CO}$, and PM. It therefore produces higher NOx pollution than diesel [164-170]. Table 11 describes the cumulative emissions adjustments for B-20 and B-100 reported by the EPA. Reports often display slightly lower emission rates of different harmful substances, such as nitro-polyaromatic hydrocarbons, PAH, and aldehydes, for biodiesel and biodiesel mixes [37,171,172]. Table 12 reveals diesel and biodiesel $\mathrm{CO}_{2}$ pollution levels, accordingly. Additionally, the possible mitigation of mid- and long-term $\mathrm{CO}_{2}$ emissions generated from biodiesel substitutes can be seen in Table 13. 

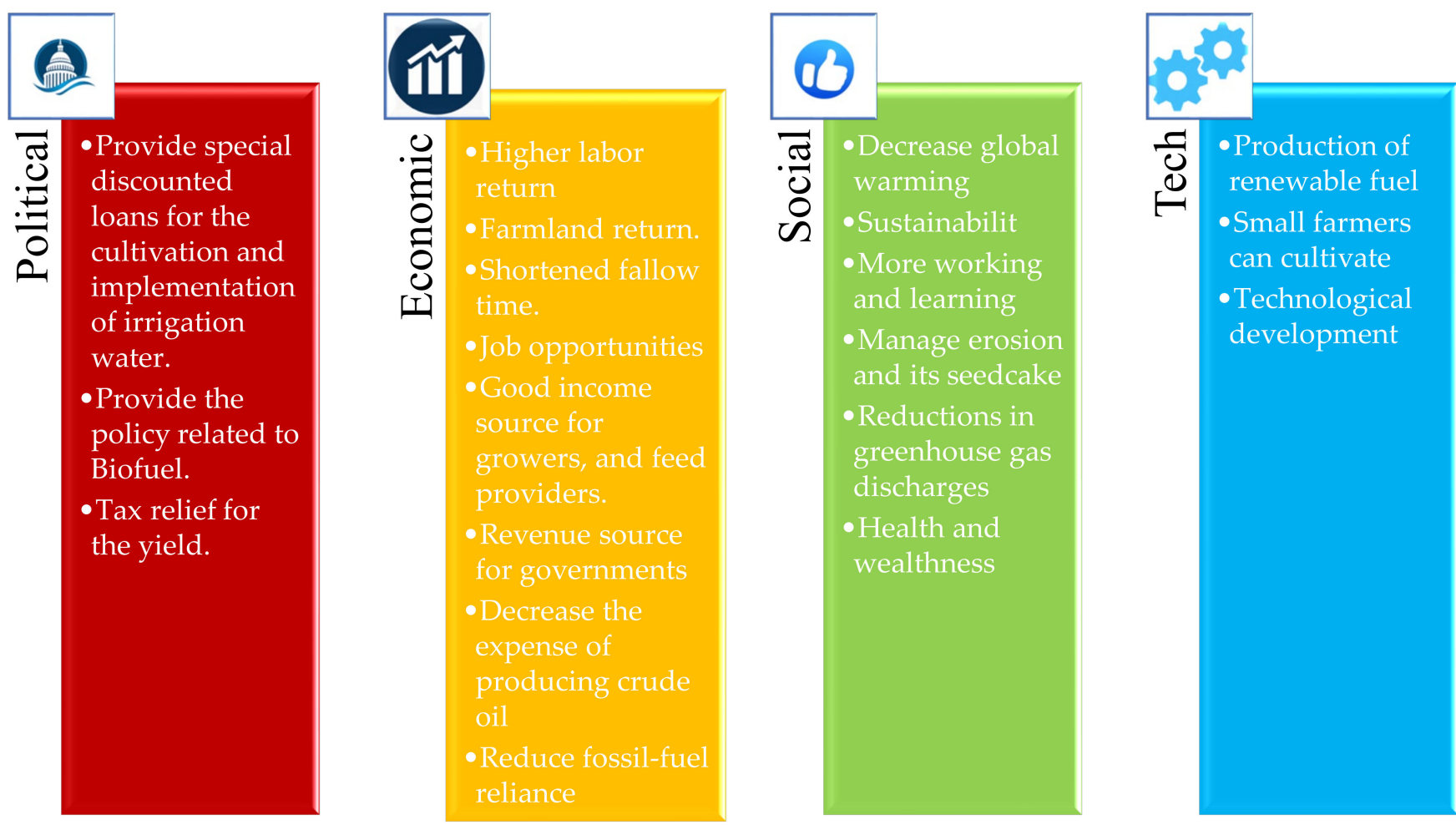

Figure 13. Political, economic, social, and tech (PEST) analysis.

Table 11. The average effect of $20 \%$ and $100 \%$ biodiesel on heavy-duty emissions compared to average typical diesel $[37,171,172]$.

\begin{tabular}{ccc}
\hline Air Pollutant & $\begin{array}{c}\text { Change for B-20 } \\
(\mathbf{\%})\end{array}$ & $\begin{array}{c}\text { Change for B-100 } \\
\mathbf{( \% )}\end{array}$ \\
\hline Nox & +2.0 to -2 & +10 \\
PM & -10.1 & -47 \\
CO & -11.0 & -48 \\
Hydrocarbon & -21.1 & -67 \\
Sulfates & -20 & -100 \\
PAH (polycyclic aromatic & -13 & -80 \\
hydrocarbons) & -50 & -90 \\
nPAH (nitrated PAH's) & &
\end{tabular}

Table 12. Aspects of emissions of $\mathrm{CO}_{2}$ from biodiesel and diesel [173].

\begin{tabular}{cc}
\hline Fuel Type & $\begin{array}{c}\text { Emissions } \mathrm{CO}_{\mathbf{2}} \\
\mathbf{( k g / T J )}\end{array}$ \\
\hline Biodiesel & 70,800 \\
Diesel & 74,100 \\
\hline
\end{tabular}

Table 13. The possible $\mathrm{CO}_{2}$ emissions' mitigation generated from biodiesel [173].

\begin{tabular}{cccc}
\hline Parameter & Unit & $\begin{array}{c}\text { Middle Term } \\
\mathbf{( 2 0 1 0 - 2 0 1 5 )}\end{array}$ & $\begin{array}{c}\text { Long Term } \\
\mathbf{( 2 0 1 5 - 2 0 2 5 )}\end{array}$ \\
\hline Substitution & Ton oil & $6,000,000$ & $16,000,000$ \\
Mitigation of $\mathrm{CO}_{2}$ emission & Million ton & 19.12 & 50.98 \\
\hline
\end{tabular}




\subsection{Environmental Impacts}

The evaluation of the long-term environmental effects of the development of biodiesel raw material is a dynamic activity. Reductions in the lifespan of carbon dioxide emissions rely on the raw material sources, the processing processes, and the assumptions about the new uses of the lands from which the feedstock was generated, particularly if the field had been wooded before [174]. One of the most desirable qualities of Jatropha is its capacity to survive scarcity and to develop in droughty and semiarid regions with poor rainwater and poor land quality $[101,108]$. In semiarid regions, Jatropha could be used to manage erosion and its seedcake could be used to boost soil $[109,175]$. The JCL plant is nitrogen-fixing and developed as among the finest methods to draw additional oxygen back into the ozone layer. Jatropha may help farmers avoid collisions with protected species as a natural barrier. The significance chain of Jatropha biofuels may result in important reductions in greenhouse gas discharges.

At the same time, additional studies are needed to determine such effects throughout the growth, power generation, and then use lifecycle. Current work suggests that Jatropha biofuel output is expected to be relatively positive relative to fossil fuel use, but the importance of such an energy balance depends on the ways of developing, transportation, and processing that appear to be unique to the plant. Nonetheless, land-use adjustments related to new farms may involve years of new plant growth to re-sequester the lost carbon through land clearing, particularly on land not initially used for agriculture. The toxicity of Jatropha will pose possible problems for the atmosphere and the health of the public. One scientist has cautioned that the curcanoleic acid present in the fuel can encourage cancer of the skin, and that field staff may be annoyed by the oil. In other areas of the country, Jatropha is often deemed invasive, such as Australia, Hawaii, and South Africa [176].

\subsection{Socio-Economic Impacts}

Jatropha oil provides higher labor and farmland returns and other advantages such as shortened fallow times. Kumar and Sharma [100] underscored some of Jatropha's cultural significances. The establishment of JTC oil conversion factories will generate job opportunities, offer a good income source for growers and feed providers, and finally, provide a significant revenue source for governments. It would also reduce fossil-fuel reliance and decrease the expense of producing crude oil [177].

\section{SWOT Analysis}

The detailed SWOT analysis for the production of biodiesel from Jatropha is presented in the Table 14.

Table 14. Strengths, weaknesses, opportunities, and threats analysis for the production of biodiesel from Jatropha.

\section{Strengths}

References

- Jatropha is a non-edible source of oil.

- Jatropha Curcas has approximately 800 species, which in return belongs to some 321. genera

- It has a higher yield (Jatropha can produce more than 1000 barrels per square mile per year-the seed oil content is $55-60 \%$ ).

- $\quad$ Less toxic than fossil-fuel emissions.

- It is a source of Renewable Energy.

- It can rise in the desert, mid-arid, and wastelands.

- Able to maintain dunes, serve as a windbreak, and combat desertification.

- Growing it costs just about nothing.

- Comparatively, certain TBO varieties have strong oil content in plants.

- It is a perennial crop with a long lifecycle of 30 years. 
Table 14. Cont.

- It is not climate-sensitive.

- In the atmosphere, it stabilizes carbon dioxide.

- It can be used as sustainable manure for plant leaves and de-oiled cake.

- As it burns without releasing smoke, the oil can be used as an illuminant.

- Propagation is simple (a cut that is forced into the earth should take root).

- The plant Jatropha Curcas is resistant to disease.

- The technology of fuel production (transesterification and extraction process) in Indian conditions is an easy and tested technology.

\section{Weaknesses}

Reference

- No observations in tried and tested farming.

- Oil content varies.

- $\quad$ Shortage of high-quality seeds, and content for planting.

- $\quad$ Long seed gestation time.

- $\quad$ Leaves and seeds are poisonous to both humans and wildlife.

- No commercial production with enough farming inputs available.

- The information is all our assumptions.

- No economic feasibility for mono-crop production.

- Toxic effects are based on many elements (phorbol esters, trypsin inhibitors, curcains, and many others) that make a difficult and complex method of full detoxification.

- No protocol for the efficient use of by-products accessible.

- Genuine and accurate details and knowledge not accessible.

- It is impossible to have vegetative propagation activities removed from the farm.

- Any species suffer from illness and pests.

- Unsynchronized ripeness of fruit.

\section{Opportunity}

Reference

- Small development time as opposed to other non-edible forms of oil.

- Jatropha oil provides higher labor and farmland returns as well as other advantages, including shorter fallow times.

- Total jobs should come from planting, seed selection, extraction of oil, biodiesel production, and regional distribution

- $\quad$ Ever rising price of crude oil.

- It does not waste the terrestrial nutrients.

- A dark blue dye is made from J. Curcas' bark that is used to color fabric, fishing nets, etc.

- In certain countries, the oil is used widely to produce soap as it has a very strong saponification benefit.

- In terms of resources and work generation, it is ideal for developed countries.

- It does not involve a costly rotation of the crops.

- The by-product of J. Curcas seeds contains high phosphorous, potassium, and nitrogen used for fish feed, household animal feed, and fertilizer in the land.

- Glycerin, the biodiesel by-product, is beneficial.

- $\quad$ They do not need fertilizers.

- Its cake could be used to produce biogas which can be used domestically as a fuel for home cooking.

- The plant reuses $100 \%$ of the $\mathrm{CO}_{2}$ emissions generated by biodiesel combustion.

- Use biotechnology to promote key outcomes.

- Carbon worth compensation (Kyoto Protocol).

- $\quad$ Better cultivable wasteland use.

- It is required for sustaining huge demand in large quantities.

- $\quad$ Power creating jobs in rural areas. 
Table 14. Cont.

\section{Threat}

Reference

- Materials are expensive to produce.

- Water is a shortage and a limited resource.

- Downstream complicated processes can minimize performance.

- Over-advertising.

- No framework for competitive procurement present in the industry.

- $\quad$ Small (NO) price assistance to seed.

- The requirement of vast amounts of seeds also satisfies the requirement for $5 \%$ diesel blending.

- Uncertainty regarding retail values.

- Input products are malpractice.

- Plenty of false information.

\section{Barriers to Jatropha Curcas}

Despite today's volatile biodiesel market, biodiesel is expected to generate a lot of public attention worldwide in the not too distant future. Jatropha Curcas biodiesel is a good prospect for large-scale biodiesel production among the numerous feedstocks available for biodiesel production, as it can minimize fuel costs compared to other alternative feedstocks. Although, several barriers obstruct the large-scale production of biodiesel from Jatropha Curcas. In this context, Figure 14 displays the most significant barriers to Jatropha Curcas biodiesel production.

\section{Regulatory and Policy Barriers}

- Lack of adequate regulations and power production oversight

- Clarity problems in deployment program policy.

- Lack of enough stimulus.

- Problems of Effective Interconnections.

- Uncertainty over policy among shareholders.

- Absence of a system for product promotion.

- Problems relating to the land allotment.

\section{Economic and Social Barriers}

- Difficulty having project funding.

- Problems relating to the bankability of project-related contracts.

- Poor business systems.

- Business uncertainty.

- Shortage of association involvement

\section{Institutional Barriers}

- Constrained resources to educate several workers

- Inadequate know-how for different technologies.

- Constrained involvement in-country R\&D.

\section{Technical Barriers}

- Shortage of valid and credible data for the feasibility analysis.

- The achievement of danger is related to technologies.

- Reliance on overseas technologies.

- Shortened modernization of extant programs.

Figure 14. Barriers to Jatropha Curcas biodiesel. 


\section{Projected Actions}

It is clear from the previous discussion that biodiesel is a substantial alternative for an energy-intensive country to cope with its environmental and economic crisis. This study proposed a simple and rational approach by extracting temporary results from these studies to address previous studies' shortcomings. Modern biodiesel planning has importance where wheat, sugar cane, and cotton are in high demand for the region, such as in Pakistan. In this situation, encouraging farm workers to grow Jatropha is a radical change. It can only be achieved in areas where canal/land resources are limited, limiting the above crops' cultivation. The Pakistani government supports the development of Jatropha in these areas by providing canal/groundwater drip irrigation that will improve production and benefit. It would also secure a sustained supply of non-edible oils by decreasing reliance on rainwater, along with these advantages. Due to this method's simplicity and reliability, continuous feeding of inedible biodiesel oil through a microscope can add additional economic benefits.

Given the high fatty acid content of Jatropha oils, the acidic esterification method can be used in a two-step process following ultra-catalytic transesterification. Additionally, to obtain biodiesel, maximum product performance must be achieved through value creation. Plans to grow local biodiesel have been redesigned to bring this idea to life. The proposed policy suggests that nearby ethanol would be the best location for biodiesel factories. Such cogeneration refineries already have biomass and biomass/biogas digesters that can integrate fired power plants into our network. When natural gas/energy runs out in the environment, fermented ethanol can purify biogas. It can be used as a supplement to generate gas or electricity. In contrast to this method, if the plant is close to the community, the shoots can be separated and turned into animal feed and fertilizer. The biodiesel produced in this way can be used as fuel in nearby areas or transported to a nearby city after mixing. The synthetic glycerin will be used directly in the fuel cell and reduce the demand for electricity from the biodiesel plant's main grid.

\section{Policy Suggestions and Future Routes}

This research emphasized the value of biodiesel in lowering the adverse environmental and economic impact of diesel fuel. This major transition still requires policy, strategic, and budget support. This study highlighted biodiesel's importance in the environmental and economic impact of mineral oil on oil prices. However, these major changes are not in line with state plans and budgets. As this study suggests, incorporating biodiesel into the energy mix is as important as green energy for tackling the oil problem. Policy needs to be reconsidered and ultimately followed by the Pakistani government's example with its acceptance of the reforms mentioned above [183,184].

- The government will have to provide special loans for the cultivation and implementation of irrigation water.

- The Government of Pakistan will formulate a short-, medium-, and long-term strategy for biodiesel development through appropriate review and adaptation.

- Non-vegetable oils must be used as energy crops, and effective market strategies must be used to increase their demand, which may increase if there is no systematic development for biodiesel, including sugar cane. The system exists.

- In addition to the source of knowledge, more work will be carried out on animal feed that keeps it in the food chain.

- Governments can introduce possibilities to generate energy from biodiesel products.

- The Pakistani government must empower small- and medium-sized businesses and allow aid to increase biodiesel production in rural areas.

- Established barren land should increase non-vegetable oil cultivation by providing new irrigation methods for the proposed land.

\section{Conclusions}

The major points of the present study are summarized below: 
- Pakistan heavily depends on fossil fuels, and there is a need to adopt renewable resources that will help the country's economy.

- The biodiesel output from Jatropha Curcas provides several social, environmental, and economic advantages for Pakistan, and therefore can play a major role in solving the issues of Pakistan's energy crisis.

- Unlike other feedstocks, this latent Jatropha Curcas requires insignificant investment for cultivation and unskilled manpower, that is also low in developing countries such as Pakistan. Hence, it provides employment opportunities for the people of rural areas.

- This is high-yield plant that is fully utilized, the seed content can be used in the extraction of high-performing biogas diesel, moreover, it is also used in producing soap that is enriched in glycerin content, and even the remnants of this plant can be used as an organic fertilizer.

- Jatropha is one of the best alternative feedstocks for producing biodiesel, which provides immediate and sustainable benefits for greenhouse emissions over all other biodiesel raw inputs.

- Internationally, Jatropha has generated value for scientists as it is a non-edible oil and could be used in testing in diesel engines for manufacturing biodiesel with the same or greater output outcomes.

- The trouble with biodiesel from Jatropha is its huge content of fatty acid. Besides, filtration and transesterification processes are also needed to improve the oil properties of biodiesel before admixing.

- Biodiesel is one of those replacements and has the tremendous ability to become part of a possible renewable energy mix.

- The imports of petroleum products in Pakistan were 11.84 million tons in 2018-2019, which cost $\$ 983.3$ million USD. By cultivating the Jatropha Curcas in $25 \%$ of the barren land, Pakistan can cut-off $\sim 2.93$ million tons of imports of petroleum products and save USD $\sim 2$ billion USD reserves.

- The government of Pakistan should make a policy to develop and promote biofuels as an industry. To attract the investment, this needs to be made attractive by designing special allowance and relief packages for this industry. Further studies may advance this biodiesel energy to generate electricity. AEDB's and PSO's should fund research grants to universities to make maximum use of his lucrative source of energy.

Author Contributions: Conceptualization, H.Y., Y.H.T., F.S. and M.A.J.; methodology, H.Y. and M.M.J.; validation, H.Y. and M.M.J.; formal analysis, H.Y. and M.M.J.; investigation, H.Y., F.S., and M.U.A.; resources, Y.H.T., F.S., M.A.M., and M.U.A.; data curation, H.Y., S.A. and M.A.J.; writingoriginal draft preparation, H.Y., M.M.J., Y.H.T., and F.S.; writing-review and editing, F.S., H.Y., and S.A.; visualization, H.Y. and M.A.M.; supervision Y.H.T. and F.S.; project administration, Y.H.T. and F.S.; funding acquisition, Y.H.T. and F.S. All authors have read and agreed to the published version of the manuscript.

Funding: This research was funded by the Ministry of Higher Education (MOHE) of Malaysia (Fundamental Research Grant Scheme (FRGS) 203.PMEKANIK.6071444).

Institutional Review Board Statement: Not applicable.

Informed Consent Statement: Not applicable.

Data Availability Statement: Not applicable.

Acknowledgments: The authors would like to acknowledge the Khwaja Fareed University of Engineering and Information Technology, Rahim Yar Khan, and Universiti Sains Malaysia, Malaysia, for their support for this study. Also acknowledged the support provided by Engr. Muhammad Zubair Mustafa (a graduate of the Khwaja Fareed University of Engineering \& Information Technology, Rahim Yar Khan, Pakistan) for organizing the figures.

Conflicts of Interest: The authors declare no conflict of interest. 


\section{Nomenclature}

\begin{tabular}{|c|c|}
\hline \multicolumn{2}{|l|}{ Abbreviations } \\
\hline AEDB & Alternate Energy Development Board \\
\hline ARE & Alternate and renewable energy \\
\hline ARETs & Alternate and renewable energy technologies \\
\hline ASTM & American Society for Testing and Materials \\
\hline B-5 & $5 \%$ biodiesel, $95 \%$ diesel blend \\
\hline B-10 & $10 \%$ biodiesel, $90 \%$ diesel blend \\
\hline B-20 & $20 \%$ biodiesel, $80 \%$ diesel blend \\
\hline B-100 & Neat biodiesel \\
\hline $\mathrm{CH}_{2} \mathrm{~N}_{2}$ & Diazomethane \\
\hline $\mathrm{CNG}$ & Compressed natural gas \\
\hline $\mathrm{CO}$ & Carbon monoxide \\
\hline $\mathrm{CO} 2$ & Carbon dioxide \\
\hline ECC & Economic Coordinate Committee \\
\hline EKC & Environmental Kuznets curve \\
\hline EPA & Environmental Protection Agency \\
\hline EU & European Union \\
\hline GDP & Gross domestic product \\
\hline GoP & Government of Pakistan \\
\hline $\mathrm{HC}$ & Hydrocarbons \\
\hline HEC & Higher Education Commission of Pakistan \\
\hline HDIP & Pakistan's Hydrocarbon Development Institute \\
\hline ISES & International Solar Energy Society \\
\hline $\mathrm{J}$. & Jatropha \\
\hline JCL & Jatropha Curcas linnaeus \\
\hline KTONs & Kilotons \\
\hline $\mathrm{KOH}$ & Potassium hydroxide \\
\hline MOCC & Pakistan's Ministry of Climate Change \\
\hline MM CFT & Million cubic feet \\
\hline MT & Million tons \\
\hline MTP & Mid-Term Policy \\
\hline $\mathrm{NaOH}$ & Sodium hydroxide \\
\hline NED & $\begin{array}{l}\text { Nadirshaw Eduljee Dinshaw University of Engineering } \\
\text { and Technology, Sindh, Pakistan }\end{array}$ \\
\hline NEPRA & National Electric Power Regulatory Authority \\
\hline NOx & Nitrogen oxides \\
\hline NUST & National University of Sciences and Technology Islamabad, Pakistan \\
\hline OGRA & Oil and Gas Regulatory Authority \\
\hline OMCs & Oil Marketing Companies \\
\hline PAH & Polycyclic Aromatic Hydrocarbons \\
\hline PARC & Agricultural Research Council of Pakistan \\
\hline PAK-EPA & Pakistan's Environmental Protection Agency \\
\hline PCAT & Appropriate Technology Council of Pakistan \\
\hline PCRET & Pakistan Council For Renewable Energy Technology \\
\hline PKR & Pakistan rupees \\
\hline PM & Particulate matter \\
\hline PSO & Pakistan State Oil \\
\hline QUEST & $\begin{array}{l}\text { Quaid-e-Azam University Of Engineering, Science, and } \\
\text { Technology Nawabshah, Sindh, Pakistan }\end{array}$ \\
\hline $\mathrm{R} \& \mathrm{D}$ & Research and development \\
\hline RSB & Sustainable biofuels roundtable \\
\hline $\mathrm{SO} 2$ & Sulfur dioxide \\
\hline SWOT & Strength, weakness, opportunity, and threats \\
\hline US\$ or USD & United States Dollars \\
\hline WWF & World Wildlife Fund \\
\hline
\end{tabular}




\section{References}

1. Silitonga, A.S.; Atabani, A.E.; Mahlia, T.M.I.; Masjuki, H.H.; Badruddin, I.A.; Mekhilef, S. A review on prospect of Jatropha curcas for biodiesel in Indonesia. Renew. Sustain. Energy Rev. 2011, 15, 3733-3756. [CrossRef]

2. Ministry of Finance Division, Government of Pakistan. Pakistan Economic Survey 2019-20; Ministry of Finance Division, Government of Pakistan: Islamabad, Pakistan, 2020.

3. World Population Review. Pakistan Population 2020. Available online: https://worldpopulationreview.com/countries/pakistanpopulation/ (accessed on 6 June 2020).

4. Irfan, M.; Zhao, Z.; Ahmad, M.; Mukeshimana, M.C. Solar Energy Development in Pakistan: Barriers and Policy Recommendations. Sustainability 2019, 14, 1206. [CrossRef]

5. Ministry of Finance Division, Government of Pakistan. Pakistan Economic Survey 2018-19; Ministry of Finance Division, Government of Pakistan: Islamabad, Pakistan, 2019.

6. Yaqoob, H.; Teoh, Y.H.; Ud Din, Z.; Sabah, N.U.; Jamil, M.A.; Mujtaba, M.A.; Abid, A. The potential of sustainable biogas production from biomass waste for power generation in Pakistan. J. Clean. Prod. 2021, 307, 127250. [CrossRef]

7. Wakeel, M.; Chen, B.; Jahangir, S. Overview of energy portfolio in Pakistan. Energy Procedia 2016, 88, 71-75. [CrossRef]

8. Ahmed, S.; Mahmood, A.; Hasan, A.; Ahmad, G.; Sidhu, S.; Fasih, M.; Butt, U. A comparative review of China, India and Pakistan renewable energy sectors and sharing opportunities. Renew. Sustain. Energy Rev. 2016, 57, 216-225. [CrossRef]

9. Sharma, A.; Srivastava, J.; Kumar, S.; Kumar, A. Wind energy status in India: A short review. Renew. Sustain. Energy Rev. 2012, 16, 1157-1164. [CrossRef]

10. Yaqoob, H.; Teoh, Y.H.; Jamil, M.A.; Gulzar, M. Potential of tire pyrolysis oil as an alternate fuel for diesel engines: A review. J. Energy Inst. 2021, 96, 1-17. [CrossRef]

11. Yaqoob, H.; Teoh, Y.H.; Goraya, T.S.; Sher, F.; Jamil, M.A.; Rashid, T.; Yar, K.A. Energy evaluation and environmental impact assessment of transportation fuels in Pakistan. Case Stud. Chem. Environ. Eng. 2021, 3, 100081. [CrossRef]

12. Chen, L.; Lin, Y. Does Air Pollution Respond to Petroleum Price? Int. J. Appl. Econ. 2015, 12, 104-125.

13. Ritchie, H.; Roser, M. $\mathrm{CO}_{2}$ and Greenhouse Gas Emissions. Available online: https://ourworldindata.org/co2-and-othergreenhouse-gas-emissions (accessed on 9 June 2021).

14. Yaqoob, H.; Teoh, Y.H.; Sher, F.; Jamil, M.A.; Nuhanović, M.; Razmkhah, O.; Erten, B. Tribological Behaviour and Lubricating Mechanism of Tire Pyrolysis Oil. Coatings 2021, 11, 386. [CrossRef]

15. The Encyclopedia of Earth. Energy Profile of Indonesia. 2010. Available online: http://www.eoearth.org/article/ EnergyprofileofIndonesia (accessed on 6 June 2020).

16. Pandey, A. Handbook of Plant-Based Biofuels, 1st ed.; Taylor \& Francis Group: Abingdon, UK, 2008.

17. Yaqoob, H.; Teoh, Y.H.; Sher, F.; Farooq, M.U.; Jamil, A.; Kausar, Z.; Sabah, N.U.; Shah, M.F.; Zia, H.; Rehman, U. Potential of Waste Cooking Oil Biodiesel as Renewable Fuel in Combustion Engines: A Review. Energies 2021, 14, 2565. [CrossRef]

18. Teoh, Y.H.; How, H.G.; Sher, F.; Le, T.D.; Nguyen, H.T.; Yaqoob, H. Fuel Injection Responses and Particulate Emissions of a CRDI Engine Fueled with Cocos nucifera Biodiesel. Sustainability 2021, 13, 4930. [CrossRef]

19. Teoh, Y.H.; How, H.G.; Sher, F.; Le, T.D.; Ong, H.C.; Nguyen, H.T.; Yaqoob, H. Optimization of Fuel Injection Parameters of Moringa oleifera Biodiesel-Diesel Blend for Engine-Out-Responses Improvements. Symmetry 2021, 13, 982. [CrossRef]

20. Yaqoob, H.; Teoh, Y.H.; Jamil, M.A.; Rasheed, T.; Sher, F. An Experimental Investigation on Tribological Behaviour of Tire-Derived Pyrolysis Oil Blended with Biodiesel Fuel. Sustainability 2020, 12, 9975. [CrossRef]

21. Hussain, F.; Alshahrani, S.; Abbas, M.M.; Khan, H.M.; Jamil, A.; Yaqoob, H.; Soudagar, M.E.M.; Imran, M.; Ahmad, M.; Munir, M. Waste Animal Bones as Catalysts for Biodiesel Production; A Mini Review. Catalysts 2021, 11, 630. [CrossRef]

22. Yaqoob, H.; Teoh, Y.H.; Jamil, M.A.; Din, Z.U.; Ul Hassan, M.; Jamil, M.; How, H.G. Feasibility Study of a 50 MW wind farm project in Pakistan. J. Adv. Res. Fluid Mech. Therm. Sci. 2020, 74, 27-42. [CrossRef]

23. Sheikh, S.R.; Shah, S.H.; Rauf, U.; Rauf, F.; Kausar, Z.; Aziz, U.; Shah, M.F.; Yaqoob, H.; Niazi, M.B. A Low-Cost Sustainable Energy Solution for Pristine Mountain Areas of Developing Countries. Energies 2021, 14, 3160. [CrossRef]

24. Jamil, M.A.; Yaqoob, H.; Farooq, M.U.; Teoh, Y.H.; Xu, B.; Mahkamov, K.; Sultan, M.; Ng, K.C.; Shahzad, M.W. Experimental Investigations of a Solar Water Treatment System for Remote Desert Areas of Pakistan. Water 2021, 13, 1070. [CrossRef]

25. Engelmann, W.; Von Hohendorff, R. Chapter 14-Regulatory Challenges in Nanotechnology for Sustainable Production of Biofuel in Brazil. In Sustainable Bioenergy; Rai, M., Ingle, A.P.B.T.-S.B., Eds.; Elsevier: Amsterdam, The Netherlands, 2019 ; pp. 367-381. ISBN 978-0-12-817654-2.

26. Demirbas, A.H.; Demirbas, I. Importance of rural bioenergy for developing countries. Energy Convers. Manag. 2007, 48, 2386-2398. [CrossRef]

27. Yaqoob, H.; Teoh, Y.H.; Sher, F.; Jamil, M.A.; Murtaza, D.; Qubeissi, A.M.; Hassan, M.U.I.; Mujtaba, M.A. Current Status and Potential of Tire Pyrolysis Oil Production as an Alternative Fuel in Developing Countries. Sustainability 2021, 13, 3214. [CrossRef]

28. U.S. Energy Information Administration. Total Biofuels Production (Thousand Barrels Per Day). Available online: http://tonto. eia.gov $/$ cfapps $/$ ipdbproject $/$ iedindex3.cfm?tid=79\&pid=79\&aid=\%0A1\&cid=\&syid=2000\&eyid=2008\&unit=TBPD (accessed on 6 June 2020).

29. Pakistan State Oil. Bio-Diesel Initiative: A Step towards a Cleaner and Self Sufficient Pakistan; Pakistan State Oil: Islamabad, Pakistan, 2008; pp. 1-4. 
30. Saravanan, A.P.; Mathimani, T.; Deviram, G.; Rajendran, K.; Pugazhendhi, A. Biofuel policy in India: A review of policy barriers in sustainable marketing of biofuel. J. Clean. Prod. 2018, 193, 734-747. [CrossRef]

31. Hao, H.; Liu, Z.; Zhao, F.; Ren, J.; Chang, S.; Rong, K.; Du, J. Biofuel for vehicle use in China: Current status, future potential and policy implications. Renew. Sustain. Energy Rev. 2018, 82, 645-653. [CrossRef]

32. Arshad, M.; Abbas, M.; Iqbal, M. Ethanol production from molasses: Environmental and socioeconomic prospects in Pakistan: Feasibility and economic analysis. Environ. Technol. Innov. 2019, 14, 100317. [CrossRef]

33. Cutz, L.; Tomei, J.; Nogueira, L.A.H. Understanding the failures in developing domestic ethanol markets: Unpacking the ethanol paradox in Guatemala. Energy Policy 2020, 145, 111769. [CrossRef]

34. Knothe, G. Analyzing Biodiesel: Standards and Other Methods. J. Am. Oil Chem. Soc. 2006, 83, 823-833. [CrossRef]

35. Nakpong, P.; Wootthikanokkhan, S. High free fatty acid coconut oil as a potential feedstock for biodiesel production in Thailand. Renew. Energy 2010, 35, 1682-1687. [CrossRef]

36. Biodiesel from Triglycerides via Transesterification. In Biodiesel; Springer: London, UK, 2008.

37. Koh, M.Y.; Idaty, T.; Ghazi, M. A review of biodiesel production from Jatropha curcas L. oil. Renew. Sustain. Energy Rev. 2011, 15, 2240-2251. [CrossRef]

38. Yusuf, N.N.A.N.; Kamarudin, S.K.; Yaakub, Z. Overview on the current trends in biodiesel production. Energy Convers. Manag. 2011, 52, 2741-2751. [CrossRef]

39. Leung, D.Y.C.; Wu, X.; Leung, M.K.H. A review on biodiesel production using catalyzed transesterification. Appl. Energy 2010, 87, 1083-1095. [CrossRef]

40. Khan, N.A.; Dessouky, H. Prospect of biodiesel in Pakistan. Renew. Sustain. Energy Rev. 2009, 13, 1576-1583. [CrossRef]

41. Marchetti, J.M.Ã.; Miguel, V.U.; Errazu, A.F. Possible methods for biodiesel production. Renew. Sustain. Energy Rev. 2007, 11, 1300-1311. [CrossRef]

42. Balat, M. Potential alternatives to edible oils for biodiesel production-A review of current work. Energy Convers. Manag. 2011, 52, 1479-1492. [CrossRef]

43. Achten, W.M.M.J.; Verchot, L.; Franken, Y.J.; Mathijs, E.; Singh, V.P.; Aerts, R.; Muys, B. Jatropha bio-diesel production and use. Biomass Bioenergy 2008, 32, 1063-1084. [CrossRef]

44. Parawira, W. Biodiesel production from Jatropha curcas: A review. Sci. Res. Essays 2010, 5, 1796-1808.

45. Dillon, H.S.; Laan, T.; Dillon, H.S. BIOFUELS-AT WHAT COST? Government Support for Ethanol and Biodiesel in Indonesia; Global Subsidies Initiative: Geneva, Switzerland, 2008.

46. Atadashi, I.M.; Aroua, M.K.; Aziz, A.A. High quality biodiesel and its diesel engine application: A review. Renew. Sustain. Energy Rev. 2010, 14, 1999-2008. [CrossRef]

47. Demirbas, A. Importance of biodiesel as transportation fuel. Energy Policy 2007, 35, 4661-4670. [CrossRef]

48. Hassan, M.H.; Kalam, A. An overview of biofuel as a renewable energy source: Development and challenges. Procedia Eng. 2013, 56, 39-53. [CrossRef]

49. Lim, S.; Teong, L.K. Recent trends, opportunities and challenges of biodiesel in Malaysia: An overview. Renew. Sustain. Energy Rev. 2010, 14, 938-954. [CrossRef]

50. Sorda, G.; Banse, M.; Kemfert, C. An overview of biofuel policies across the world. Energy Policy 2010, 38, 6977-6988. [CrossRef]

51. Yacobucci, B.D.; Bracmort, K.S. Calculation of Lifecycle Greenhouse Gas. Emissions for the Renewable Fuel Standard (RFS); Congressional Research Service: Washington, DC, USA, 2009.

52. The Digests Biofuels Mandates around the World. Available online: https://www.biofuelsdigest.com/bdigest/2019/01/01 /biofuels-mandates-around-the-world-2019/bd-ts-010219-mandates-19/ (accessed on 16 June 2021).

53. Czyrnek-delêtre, M.; Smyth, B.M.; Murphy, J.D. Beyond carbon and energy: The challenge in setting guidelines for life cycle assessment of biofuel systems. Renew. Energy 2017, 105, 436-448. [CrossRef]

54. Smyth, B.M.; Gallachóir, B.P.Ó.; Korres, N.E.; Murphy, J.D. Can we meet targets for biofuels and renewable energy in transport given the constraints imposed by policy in agriculture and energy? J. Clean. Prod. 2020, 18, 1671-1685. [CrossRef]

55. Su, Y.; Zhang, P.; Su, Y. An overview of biofuels policies and industrialization in the major biofuel producing countries. Renew. Sustain. Energy Rev. 2015, 50, 991-1003. [CrossRef]

56. Lima, M.G.B.; Gupta, J. The extraterritorial dimensions of biofuel policies and the politics of scale: Live and let die? Third World Q. 2014, 35, 392-410. [CrossRef]

57. Kumar, S.; Shrestha, P.; Salam, P.A. A review of biofuel policies in the major biofuel producing countries of ASEAN: Production, targets, policy drivers and impacts. Renew. Sustain. Energy Rev. 2013, 26, 822-836. [CrossRef]

58. Jayed, M.H.; Masjuki, H.H.; Kalam, M.A.; Mahlia, T.M.I.; Husnawan, M.; Liaquat, A.M. Prospects of dedicated biodiesel engine vehicles in Malaysia and Indonesia. Renew. Sustain. Energy Rev. 2011, 15, 220-235. [CrossRef]

59. Republic of the Philippines. Republic Act no. 9367. An Act to Direct the Use of Biofuels. Biofuels Act of 2006, Manila, Philippines. Available online: http:/ / www.senate.gov.ph/republic_acts/ra9367.pdf (accessed on 6 June 2020).

60. Labios, A.E.M.G. The Philippine Biofuels Program: The Social \& Economic Impacts. Available online: http://www.unescap. org/esd/\%0AEnergy-Security-and-Water-Resources/energy/dialogue/biofuels/benefit_chal\%0Alenges / presentations / Presentations\%2520on\%2520Sep\%252024/ANTONIO\%2520E.\%25\%0A20LABIOS_Philipines.pdf (accessed on 10 May 2021). 
61. Economic Times. Make Ethanol from Surplus Food Grains: Draft Policy. 2017. Available online: https://economictimes. indiatimes.com/industry/energy/oil-gas/indian-bio-fuel-market-to-grow-to-rs-1-lakh-crore-dharmendra-pradhan/articleshow/ 61758500.cms? from $=\mathrm{mdr}$ (accessed on 14 June 2020).

62. Koljonen, T.; Flyktman, M.; Lehtilä, A.; Pahkala, K.; Peltola, E. The role of CCS and renewables in tackling climate change. Energy Procedia 2009, 1, 4323-4330. [CrossRef]

63. Government of Pakistan. Alternative and Renewable Energy Policy 2011; Government of Pakistan: Islamabad, Pakistan, 2011.

64. Solangi, K.H.; Islam, M.R.; Saidur, R.; Rahim, N.A.; Fayaz, H. A review on global solar energy policy. Renew. Sustain. Energy Rev. 2011, 15, 2149-2163. [CrossRef]

65. Islam, M.T.; Shahir, S.A.; Uddin, T.M.I.; Saifullah, A.Z.A. Current energy scenario and future prospect of renewable energy in Bangladesh. Renew. Sustain. Energy Rev. 2014, 39, 1074-1088. [CrossRef]

66. Bazmi, A.A.; Zahedi, G. Sustainable energy systems: Role of optimization modeling techniques in power generation and supply-A review. Renew. Sustain. Energy Rev. 2011, 15, 3480-3500. [CrossRef]

67. Mukherjee, I.; Sovacool, B.K. Sustainability principles of the Asian Development Bank's (ADB's) energy policy: An opportunity for greater future synergies. Renew. Energy 2012, 48, 173-182. [CrossRef]

68. Braadbaart, F.; Poole, I.; Huisman, H.D.J.; van Os, B. Fuel, Fire and Heat: An experimental approach to highlight the potential of studying ash and char remains from archaeological contexts. J. Archaeol. Sci. 2012, 39, 836-847. [CrossRef]

69. Ali, S.I. City District Government of Karachi (CDGK) to Grow Jatropha Plants. Available online: https://nation.com.pk/14-Jul2009/cdgk-to-grow-jatropha-plants (accessed on 10 May 2020).

70. Government of Pakistan. Alternative and Renewable Energy Policy 2019; Government of Pakistan: Islamabad, Pakistan, 2019.

71. Danish; Zhang, B.; Wang, B.; Wang, Z. Role of renewable energy and non-renewable energy consumption on EKC: Evidence from Pakistan. J. Clean. Prod. 2017, 156, 855-864. [CrossRef]

72. Zaman, K.; Mushtaq, M.; Ahmad, M.; Rustam, R. The relationship between agricultural technology and energy demand in Pakistan. Energy Policy 2012, 44, 268-279. [CrossRef]

73. Asif, M. Sustainable energy options for Pakistan. Renew. Sustain. Energy Rev. 2009, 13, 903-909. [CrossRef]

74. Mahmood, A.; Javaid, N.; Zafar, A.; Ali, R.; Ahmed, S.; Razzaq, S. Pakistan's overall energy potential assessment, comparison of LNG, TAPI and IPI gas projects. Renew. Sustain. Energy Rev. 2014, 31, 182-193. [CrossRef]

75. Tahir, S.N.A.; Rafique, M.; Alaamer, A.S. Biomass fuel burning and its implications: Deforestation and greenhouse gases emissions in Pakistan. Environ. Pollut. 2010, 158, 2490-2495. [CrossRef]

76. Khalid, M.; Kumar, S.; Shrestha, R.M. Energy, environmental and economic effects of Renewable Portfolio Standards (RPS) in a Developing Country. Energy Policy 2013, 62, 989-1001. [CrossRef]

77. Zaman, K.; Mushtaq, M.; Ahmad, M. Factors affecting commercial energy consumption in Pakistan: Progress in energy. Renew. Sustain. Energy Rev. 2013, 19, 107-135. [CrossRef]

78. Harun, M.; Ali, M.; Nazir, J.; Ahmed, N.; Hasan, B.; Islam, S.; Aziz, A.; Raman, A.; Yusoff, R.; Faisal, M. Status of biodiesel research and development in Pakistan. Renew. Sustain. Energy Rev. 2012, 16, 4396-4405. [CrossRef]

79. Rafique, M.M.; Rehman, S. National energy scenario of Pakistan-Current status, future alternatives, and institutional infrastructure: An overview. Renew. Sustain. Energy Rev. 2017, 69, 156-167. [CrossRef]

80. Mofijur, M.; Masjuki, H.H.; Kalam, M.A.; Hazrat, M.A.; Liaquat, A.M.; Shahabuddin, M.; Varman, M. Prospects of biodiesel from Jatropha in Malaysia. Renew. Sustain. Energy Rev. 2012, 16, 5007-5020. [CrossRef]

81. Demirbas, A. Progress and recent trends in biodiesel fuels. Energy Convers. Manag. 2009, 50, 14-34. [CrossRef]

82. Vianna, D.S.; Aliana, C.; Garcez, G. Brazilian Biodiesel Policy: Social and environmental considerations of sustainability. Energy 2011, 34, 645-654. [CrossRef]

83. Smeets, E.M.W.; Faaij, A.P.C.; Lewandowski, I.M.; Turkenburg, W.C. A bottom-up assessment and review of global bio-energy potentials to 2050. Prog. Energy Combust. Sci. 2007, 33, 56-106. [CrossRef]

84. Peters, C.J.; Bills, N.L.; Wilkins, J.L.; Fick, G.W. Foodshed analysis and its relevance to sustainability. Renew. Agric. Food Syst. 2008, 24, 1-7. [CrossRef]

85. Biodiesel. National Biodiesel Board (NBB). Biodiesel Sustainability Symposium. Available online: http://www.biodiesel.org/\%0 Aresources/sustainability/pdfs/minutes/STFSymposiumProceedings.\%0Apdf (accessed on 10 May 2020).

86. Biodiesel. National Biodiesel Board. Guiding Principles for Biodiesel Sustainability. Available online: https://www.biodiesel. org/what-is-biodiesel/biodiesel-basics / (accessed on 10 May 2020).

87. Achten, W.M.M.J.; Mathijs, E.; Leuven, K.U. Jatropha biodiesel fueling sustainability? Biofuels Bioprod. Biorefining 2007, 1, $283-291$. [CrossRef]

88. Ministry of Finance Division, Government of Pakistan. Pakistan Economic Survey 2009-10; Ministry of Finance Division, Government of Pakistan: Islamabad, Pakistan, 2010.

89. Azhar, M.; Zahir, M.; Zaman, K.; Mushtaq, M.; Zahoor, H. Causal links between greenhouse gas emissions, economic growth and energy consumption in Pakistan: A fatal disorder of society. Renew. Sustain. Energy Rev. 2013, 25, 166-176. [CrossRef]

90. Asif, M.; Muneer, T. Life cycle assessment of built-in-storage solar water heaters in Pakistan. Build. Serv. Eng. Res. Technol. 2006, 27, 63-69. [CrossRef]

91. Parikh, J.K. From farm gate to food plate: Energy in post-harvest food systems in south Asia. Energy Policy 1986, 14, 363-372. [CrossRef] 
92. Qazi, M.A.; Akram, M.; Ahmad, N.; Artiola, J.F.; Tuller, M. Economical and environmental implications of solid waste compost applications to agricultural fields in Punjab, Pakistan. Waste Manag. 2009, 29, 2437-2445. [CrossRef] [PubMed]

93. Saif, M.; Rehman, U.; Rashid, N.; Saif, A.; Mahmood, T.; Han, J. Potential of bioenergy production from industrial hemp (Cannabis sativa): Pakistan perspective. Renew. Sustain. Energy Rev. 2013, 18, 154-164. [CrossRef]

94. Tariq, M.; Ali, S.; Khalid, N. Activity of homogeneous and heterogeneous catalysts, spectroscopic and chromatographic characterization of biodiesel: A review. Renew. Sustain. Energy Rev. 2012, 16, 6303-6316. [CrossRef]

95. Bilgen, S. Structure and environmental impact of global energy consumption. Renew. Sustain. Energy Rev. 2014, 38, 890-902. [CrossRef]

96. Chaudhry, M.A.; Raza, R.; Hayat, S.A. Renewable energy technologies in Pakistan: Prospects and challenges. Renew. Sustain. Energy Rev. 2009, 13, 1657-1662. [CrossRef]

97. Ali, T.; Huang, J.; Yang, J. Impact assessment of global and national biofuels developments on agriculture in Pakistan. Appl. Energy 2013, 104, 466-474. [CrossRef]

98. Watts, P. Global Pulse Industry, 1st ed.; Elsevier Ltd.: Amsterdam, The Netherlands, 2011; ISBN 9780123820181.

99. Openshaw, K. A review of Jatropha curcas: An oil plant of unfulfilled promise. Biomass Bioenergy 2000, 19, 1-15. [CrossRef]

100. Kumar, A.; Sharma, S. An evaluation of multipurpose oil seed crop for industrial uses (Jatropha curcas L.): A review. Ind. Crop. Prod. 2008, 28, 1-10. [CrossRef]

101. Divakara, B.N.; Upadhyaya, H.D.; Wani, S.P.; Gowda, C.L.L. Biology and genetic improvement of Jatropha curcas L.: A review. Appl. Energy 2010, 87, 732-742. [CrossRef]

102. Garnayak, D.K.; Pradhan, R.C.; Naik, S.N.; Bhatnagar, N. Moisture-dependent physical properties of jatropha seed (Jatropha curcas L.). Ind. Crop. Prod. 2008, 27, 123-129. [CrossRef]

103. Misra, R.D.; Murthy, M.S. Jatropa-The future fuel of India. Renew. Sustain. Energy Rev. 2011, 15, 1350-1359. [CrossRef]

104. Vyas, D.K.; Singh, R.N. Feasibility study of Jatropha seed husk as an open core gasifier feedstock. Renew. Energy 2007, 32, $512-517$. [CrossRef]

105. Heller, J. Physic Nut. Jatropha curcas L. Promoting the Conservation and Use of Underutilized and Neglected Crops. Available online: http:/ / pdf.usaid.gov/pdfdocs/PNACH869.pdf (accessed on 10 May 2020).

106. Wirawan, S.S. Potential of Jatropha curcas L. Joint Task 40. In Proceedings of the ERIA Workshop, Tsukuba, Japan, 28 October 2009.

107. Capstick, R. Assessment of the Bio-Fuels Value Chain in Indonesia. Available online: http://www.amarta.net/amarta/\%0 AConsultancyReport/EN/AMARTAValueChainAssesment\%0ABiofuel.pdf (accessed on 2 May 2020).

108. Kumar, A.; Sharma, S. Potential non-edible oil resources as biodiesel feedstock: An Indian perspective. Renew. Sustain. Energy Rev. 2011, 15, 1791-1800. [CrossRef]

109. Pradhan, R.C.; Mishra, S.; Naik, S.N.; Bhatnagar, N.; Vijay, V.K. Oil expression from Jatropha seeds using a screw press expeller. Biosyst. Eng. 2011, 109, 158-166. [CrossRef]

110. Lu, H.; Liu, Y.; Zhou, H.; Yang, Y.; Chen, M.; Liang, B. Production of biodiesel from Jatropha curcas L. oil. Comput. Chem. Eng. 2009, 33, 1091-1096. [CrossRef]

111. Henning, R.K. The Jatropha System. Available online: http:/ / www.jatropha.de/ (accessed on 2 May 2020).

112. Raju, A.J.S.; Ezradanam, V. Pollination ecology and fruiting behavior in a monoecious species Jatropha curcas L. (Euphorbiaceae). Curr. Sci. 2002, 83, 1395-1398.

113. Katwal, R.P.S.; Soni, P.L. Biofuels: An opportunity for socioeconomic development and cleaner environment. Indian For. 2003, 129, 939-949.

114. Hambali, D.I.E. Prospek Pengembangan Tanaman Jarak Pagar untuk Biodiesel dan Produk Turunan Lainnya. In Proceedings of the Workshop Pendirian Kebun Bibit Sumber, Demplot dan Feasibility Study untuk Perkebunan Jarak Pagar, Bogor, Indonesia, 16-17 May 2006.

115. Pradesh, I.U.; Farm, C. Synergistic cropping of summer groundnut with Jatropha curcas-A new two-tier cropping system for Uttar Pradesh. Growth 2007, 5, 1-2.

116. Gui, M.M.; Lee, K.T.; Bhatia, S. Feasibility of edible oil vs. non-edible oil vs. waste edible oil as biodiesel feedstock. Energy 2008, 33, 1646-1653. [CrossRef]

117. Janaun, J.; Ellis, N. Perspectives on biodiesel as a sustainable fuel. Renew. Sustain. Energy Rev. 2010, 14, 1312-1320. [CrossRef]

118. Azam, M.M.; Waris, A.; Nahar, N.M. Prospects and potential of fatty acid methyl esters of some non-traditional seed oils for use as biodiesel in India. Biomass Bioenergy 2005, 29, 293-302. [CrossRef]

119. Akbar, E.; Yaakob, Z.; Kamarudin, S.K.; Ismail, M.S. Characteristic and Composition of Jatropha curcas Oil Seed from Malaysia and its Potential as Biodiesel Feedstock. Eur. J. Sci. Res. 2009, 29, 396-403.

120. Gübitz, G.M.; Mittelbach, M.; Trabi, M. Exploitation of the tropical oil seed plant Jatropha curcas L. Bioresour. Technol. 1999, 67, 73-82. [CrossRef]

121. Gunstone, F. The Chemistry of Oils and Fats: Sources, Composition, Properties and Uses; John Wiley \& Sons: Hoboken, NJ, USA, 2004; ISBN 1405116269.

122. Length, F. Chemical composition and insecticidal properties of the underutilized Jatropha curcas seed oil. Afr. J. Biotechnol. 2006, 5, 901-906.

123. Mittelbach, M. Diesel fuel derived from vegetable oils, VI: Specifications and quality control of biodiesel. Bioresour. Technol. 1996, 56, 7-11. [CrossRef] 
124. Pramanik, K. Properties and use of Jatropha Curcas oil and diesel fuel blends in compression ignition engine. Renew. Energy 2003, 28, 239-248. [CrossRef]

125. Agarwal, D.; Agarwal, A.K. Performance and emissions characteristics of Jatropha oil (preheated and blends) in a direct injection compression ignition engine. Appl. Therm. Eng. 2007, 27, 2314-2323. [CrossRef]

126. Rashid, U.; Anwar, F.; Jamil, A.; Bhatti, H. Jatropha curcas Seed Oil as a Viable Source for Biodiesel. Pak. J. Bot. $2010,42,575-582$.

127. Sarin, R.; Kumar, R.; Srivastav, B.; Puri, S.K.; Tuli, D.K.; Malhotra, R.K.; Kumar, A. Biodiesel surrogates: Achieving performance demands. Bioresour. Technol. 2009, 100, 3022-3028. [CrossRef] [PubMed]

128. Odetoye, T.E.; Ogunniyi, D.S.; Olatunji, G.A. Preparation and evaluation of Jatropha curcas Linneaus seed oil alkyd resins. Ind. Crop. Prod. 2010, 32, 225-230. [CrossRef]

129. Johanes, H.; Hirata, S. Biodiesel production from crude Jatropha curcas L. seed oil with a high content of free fatty acids. Bioresour. Technol. 2008, 99, 1716-1721. [CrossRef]

130. Thepkhun, P. Biofuels Standard \& Regulations in Thailand; Thailand Institute of Scientific and Technological Research: Pathum, Thailand, 2007.

131. Widodo, T.W.; Rahmarestia, E. Current Status of Bioenergy Development in Indonesia. In Proceedings of the Regional Forum on Bioenergy Sector Development: Challenges, Opportunies, and the Way Forward, Bangkok, Thailand, 23-25 January 2008; pp. $1-41$.

132. Parajuli, R. Jatropha curcas and Its Potential Applications; A Compilation Paper on Plantation and Application of Jatropha curcas. Renew. Sustain. Energy Rev. 2009, 15, 3733-3756.

133. Traore, S. Characterisation of a Biodiesel from an Alkali Transesterification of Jatropha curcas oil. Available online: http: / / www.jatropha.de/Journal/ Art.-Jatropha-Biodiesel-TraoreGuinea.pdf (accessed on 2 May 2020).

134. Sarin, R.; Sharma, M.; Sinharay, S.; Malhotra, R.K. Jatropha-Palm biodiesel blends: An optimum mix for Asia. Fuel 2007, 86, 1365-1371. [CrossRef]

135. Knothe, G. Structure Indices in FA Chemistry. How Relevant Is the Iodine Value? J. Am. Oil Chem. Soc. 2002, 79, 847-854. [CrossRef]

136. Forson, F.K.; Oduro, E.K.; Hammond-Donkoh, E. Performance of jatropha oil blends in a diesel engine. Renew. Energy 2004, 29, 1135-1145. [CrossRef]

137. Khan, N.A.; Usmani, J.N. Status of jatropha cultivation for biodiesel production in Pakistan. Sci. Technol. Dev. 2011, 29, 1-9.

138. Soomro, R.; Memon, R. Establishment of callus and suspension culture in Jatropha curcas. Pak. J. Bot. 2007, 39, $2431-2441$.

139. Alternative Energy Development Board. Available online: www.aedb.org (accessed on 2 May 2020).

140. Mushtaq Ahmad, H.A.J.; Shazia Sultana, M.Z.; Ullah, M.A.A.K. Prospects for the Production of Biodiesel in Pakistan. In Biofuels-Status and Perspective; IntechOpen: London, UK, 2009; p. 22.

141. Progress Report on PSOs' Biodiesel Initiative for the Promotion of Biodiesel in Pakistan. Available online: http://www.psopk. com/products_services/pdf/bio_diesel.pdf (accessed on 8 May 2020).

142. Plan for Mass Jatropha Cultivation. Available online: http://www.thebioenergysite.com/\%0Anews/3596/plan-for-massjatropha-cultivation (accessed on 5 May 2020).

143. Canadian Firm to Produce Bio-Diesel. Available online: https://www.dawn.com/news/985807/canadian-firm-to-produce-biodiesel (accessed on 11 June 2020).

144. Ahmad, M.; Khan, M.A.; Zafar, M.; Sultana, S.G.S. Indigenous plants based biodiesel resources in Pakistan. Ethnobot. Leaflet 2007, 2007, 25.

145. Shah, S.; Sharma, S.G.M. Biodiesel preparation by lipase-catalyzed transesterification of jatropha oil. Energy Fuels 2004, 18, 154-159. [CrossRef]

146. Ahmad, M.; Khan, M.A.; Zafar, M.S.S. Systematic studies of oil yielding plants and their applications as a bio-diesel resource in Pakistan. In Proceedings of the CSF-HEC Workshop on Promoting Industry Academia Linkages for Developing the KnowledgeBased Enterprise Sector in Pakistan, Rawalpindi, Pakistan, 25-27 April 2007.

147. Chakrabarti, M.H.; Usmani, J.N.; Ali, M. Techno-economic evaluation of two non-edible vegetable oil based biodiesel in Pakistan. NED Univ. J. Res. 2010, 7, 43-55.

148. Chakrabarti, M.H.; Ali, M.; Baroutian, S.S.M. Techno-economic comparison between B10 of Eruca sativa L. and other indigenous seed oils in Pakistan. Process. Saf. Environ. Prot. 2011, 89, 165-171. [CrossRef]

149. Bio-Diesel Production Plant at SSUET. Available online: https://www.thenews.com.pk/archive/print/39842-bio-dieselproduction-plant-at-ssuet (accessed on 12 June 2020).

150. Usmani, J.N. Biodiesel in Pakistan. Available online: http://www.powerasia.com.pk/icaep2007/\%0Apresentations/1st_Session/ Bio_Diesel_in_Pakistan.pdf (accessed on 12 June 2020).

151. Annual Report 2008_-Indus for All Programme. Available online: http://www.wwfpak.org/\%0Aforeverindus/pdf/290409ifap_ annualreport_2008.pdf (accessed on 10 May 2020).

152. Talal, S. SCME-NUST Prepares Cheap Alternative to Diesel. Available online: https://propakistani.pk/2011/05/04/scmenustprepares-cheap-alternative-to-diesel/ (accessed on 9 June 2020).

153. Demirbas, A. Biodiesel; Springer: London, UK, 2008.

154. Pakistan Bureau of Statistics. Land Utilization Statistics; Pakistan Bureau of Statistics: Islamabad, Pakistan, $2010 ;$ p. 11.

155. Pakistan Bureau of Statistics. Pakistan Statistical Year Book 2010; Pakistan Bureau of Statistics: Islamabad, Pakistan, 2010. 
156. Gunaseelan, V.N. Biomass estimates, characteristics, biochemical methane potential, kinetics and energy flow from Jatropha curcus on dry lands. Biomass Bioenergy 2009, 33, 589-596. [CrossRef]

157. Nevase, S.S.; Gadge, S.R.; Dubey, A.K.; Kadu, B.D. Economics of biodiesel production from Jatropha oil. J. Agric. Technol. 2012, 8, 657-662.

158. Trabucco, A.; Achten, W.M.M.J.; Bowe, C.; Aerts, R.; Van Orshoven, J.; Norgrove, L.; Muys, B. Global mapping of Jatropha curcas yield based on response of fitness to present and future climate. GCB Bioenergy 2010, 2, 139-151. [CrossRef]

159. Searchinger, T.; Heimlich, R.; Houghton, R.A.; Dong, F.; Elobeid, A.; Fabiosa, J.; Tokgoz, S.; Hayes, D.; Yu, T.H. Use of U.S. croplands for biofuels increases greenhouse gases through emissions from land-use change. Science 2008, 319, 1238-1240. [CrossRef] [PubMed]

160. Lele, S. Jatropha Curcas Plant (RatanJyot, VanErand). Available online: http:/ / www.svlele.com/jatropha_plant.htm (accessed on 27 June 2020).

161. Pimentel, D.; Marklein, A.; Toth, M.; Karpoff, M.; Paul, G.; McCormack, R.; Kyriazis, J.; Krueger, T. Biofuel Impacts on World Food Supply: Use of Fossil Fuel, Land and Water Resources. Energies 2008, 1, 41-78. [CrossRef]

162. Kesava Rao, A.V.R.; Wani, S.P.; Singh, P.; Srinivas, K.; Srinivasa Rao, C. Water requirement and use by Jatropha curcas in a semi-arid tropical location. Biomass Bioenergy 2012, 39, 175-181. [CrossRef]

163. Sujatha, M.; Reddy, T.P.; Mahasi, M.M.J. Role of biotechnological interventions in the improvement of castor (Ricinus communis L.) and Jatropha curcas L. Biotechnol. Adv. 2008, 26, 424-435. [CrossRef]

164. Jayed, M.H.; Masjuki, H.H.; Saidur, R.; Kalam, M.A.; Jahirul, M.I. Environmental aspects and challenges of oilseed produced biodiesel in Southeast Asia. Renew. Sustain. Energy Rev. 2009, 13, 2452-2462. [CrossRef]

165. Murugesan, A.; Umarani, C.; Chinnusamy, T.R.; Krishnan, M.; Subramanian, R.; Neduzchezhain, N. Production and analysis of bio-diesel from non-edible oils-A review. Renew. Sustain. Energy Rev. 2009, 13, 825-834. [CrossRef]

166. Patil, P.D.; Deng, S. Optimization of biodiesel production from edible and non-edible vegetable oils. Fuel 2009, 88, 1302-1306. [CrossRef]

167. Xue, J.; Grift, T.E.; Hansen, A.C. Effect of biodiesel on engine performances and emissions. Renew. Sustain. Energy Rev. 2011, 15, 1098-1116. [CrossRef]

168. Wassell, C.S.; Dittmer, T.P. Are subsidies for biodiesel economically efficient? Energy Policy 2006, 34, 3993-4001. [CrossRef]

169. Szulczyk, K.R.; Mccarl, B.A. Market penetration of biodiesel. Renew. Sustain. Energy Rev. 2010, 14, 2426-2433. [CrossRef]

170. Lapuerta, M.; Armas, O.; Rodríguez-Fernández, J. Effect of biodiesel fuels on diesel engine emissions. Prog. Energy Combust. Sci. 2008, 34, 198-223. [CrossRef]

171. Environmental Protection Agency (EPA). A Comprehensive Analysis of Biodiesel Impacts on Exhaust Emissions; EPA: Washington, DC, USA.

172. McCormick, R.L.; Allerman, T.L.; Yanowitz, J. Impact of Biodiesel Fuel on Pollutant Emissions from Diesel Engines; National Renewable Energy Laboratory: Golden, CO, USA.

173. Sugiyono, A. Pengembangan Bahan Bakar Nabati untuk Mengurangi Dampak Pemanasan Global. Development of Vegetable oils to Reduce Global Warming Effect. Seminar Nasional Kebijakan Pemanfaatan Lahan dalam Menanggulangi Dampak Pemenasan Global, Keluarga Mahasiswa Ilmu Tanah, Fakultas Pertanian, UGM. 2008. Available online: http://sugiyono.webs.com/paper/ p0801.pdf (accessed on 3 February 2011).

174. Knowgenix Sustainable Biodiesel Feedstock. Jatropha: A Strategic Option. 2007. Available online: http://www.knowgenix.com/ release/jatropha_PP1_Nov_07.pdf (accessed on 12 June 2020).

175. Reubens, B.; Achten, W.M.M.J.; Maes, W.H.; Danjon, F.; Aerts, R.; Poesen, J.; Muys, B. More than biofuel? Jatropha curcas root system symmetry and potential for soil erosion control. J. Arid Environ. 2011, 75, 201-205. [CrossRef]

176. German Technical Cooperation. Jatropha Reality Check: A Field Assessment of the Agronomic and Economic Viability of Jatropha and Other Oilseed Crops in Kenya 2010. Available online: http:/ / www.worldagroforestry.org/downloads/publications/PDFs/B16599.pdf (accessed on 12 June 2020).

177. Baroi, C.; Yanful, E.K.; Rahman, M.F.; Bergougnou, M. Environment Friendly Biodiesel from Jatropha Curcas: Possibilities and Challenges; Springer: Dordrecht, Germany, 2010.

178. Nilayam, R. Biodiesel Conference Towards Energy Independence-Focus on Jatropha. In Proceedings of the Conference Rashtrapati Nilayam, Bolaram, Hyderabad, India, 9-10 June 2006.

179. German Financial Cooperation with the Indonesia. Development of Jatropha curcas Oil for Bio-Energy in Rural Area. Available online: http:/ / pphp.deptan.go.id/beranda/eng.html (accessed on 10 May 2020).

180. Schill, M. Intervention Strategy for the Development of Biofuel: Challenges \& Opportunities; SNV Consultant: Vientiane, Laos, 2009.

181. Gendy, T.S.; El-Temtamy, S.A. Commercialization potential aspects of microalgae for biofuel production: An overview. Egypt. J. Pet. 2013, 22, 43-51. [CrossRef]

182. Darshini, D.; Dwivedi, P.; Glenk, K. Capturing stakeholders' views on oil palm-based biofuel and biomass utilisation in Malaysia. Energy Policy 2013, 62, 1128-1137. [CrossRef] 
183. Naqvi, S.R.; Jamshaid, S.; Naqvi, M.; Farooq, W.; Niazi, M.B.K.; Aman, Z.; Zubair, M.; Ali, M.; Shahbaz, M.; Inayat, A.; et al. Potential of biomass for bioenergy in Pakistan based on present case and future perspectives. Renew. Sustain. Energy Rev. 2018, 81, 1247-1258. [CrossRef]

184. Ali, S.; Fazal, T.; Javed, F.; Hafeez, A.; Akhtar, M.; Haider, B.; Saif ur Rehman, M.; Zimmerman, W.B.; Rehman, F. Investigating biodiesel production strategies as a sustainable energy resource for Pakistan. J. Clean. Prod. 2020, 259, 120729. [CrossRef] 